\title{
Toelichting verwachte impact van IFRS 9 en IFRS 15
}

\author{
Kees Roozen, Maarten Pronk
}

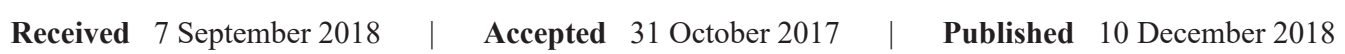

\section{Samenvatting}

IAS 8 bevat de verplichting om informatie te verstrekken over nieuwe standaarden die nog niet toegepast hoeven te worden. In de 2017-jaarrekening geldt dat met name voor IFRS 9 'Financial Instruments' en IFRS 15 'Revenue from Contracts with Customers'. Wij analyseren de informatieverstrekking door Europese beursgenoteerde corporates. De meeste ondernemingen geven de impact aan. Van de onderzochte ondernemingen geeft 9\% aan dat IFRS 9 een materiële impact heeft en voor IFRS 15 ligt dat percentage op $32 \%$. IFRS 9 heeft materiële impact op de onderdelen Classificatie en waardering en Bijzondere waardevermindering. Voor IFRS 15 worden de nadere richtlijnen over het onderkennen van prestatieverplichtingen als belangrijkste reden voor aanpassing genoemd. Bij IFRS 9 kwantificeert zo'n 30\% van de ondernemingen de impact en bij IFRS 15 is dat zo'n 50\%. De meeste ondernemingen zonder kwantitatieve indicatie geven aan dat de impact niet materieel is.

\section{Relevantie voor de praktijk}

Dit artikel geeft inzicht in de verwachte effecten van IFRS 9 en IFRS 15. Daarnaast geeft het een beeld hoe omgegaan wordt met de bepaling in IAS 8 dat, indien mogelijk, de verwachte effecten van nieuwe standaarden vermeld moeten worden. Dit is onder andere relevant voor toekomstige jaarrekeningen, zoals voor de toelichting in de jaarrekening 2018 over de verwachte effecten van de nieuwe standaard IFRS 16 'Leases' die vanaf boekjaar 2019 moet worden toegepast. Ondanks de lage percentages van materiële impact ( $9 \%$ bij IFRS 9 en 32\% bij IFRS 15) betekent dit niet dat de transitie naar IFRS 9 en IFRS 15 geen inspanning vergt van de opstellers en van de externe accountants van deze ondernemingen. Zo zal moeten worden vastgesteld dat inderdaad geen sprake is van een niet-materieel effect en de nieuwe standaarden vereisen ook aanvullende toelichtingen, zowel in de grondslagen als in de cijfermatige toelichting.

\section{Inleidling}

IFRS 9 'Financial Instruments' en IFRS 15 'Revenue from Contracts with Customers' zijn twee nieuwe standaarden die vanaf 1 januari 2018 toegepast moeten worden. IAS 8 bevat de verplichting om informatie te verstrekken over nieuwe standaarden die nog niet toegepast hoeven te worden. Vandaar dat de 2017-jaarrekening reeds informatie bevat over IFRS 9 en IFRS 15. In dit artikel analyseren wij deze informatieverstrekking om inzicht te krijgen in de verwachte effecten van deze nieuwe standaarden en om een beeld te krijgen hoe ondernemingen omgaan met de verplichting om inzicht te geven in de effecten van deze nieuwe standaarden.

Dit artikel begint met een globale beschrijving van IFRS 9 en IFRS 15. Daarna geven wij aan welke informatie verstrekt moet worden over komende standaarden en bespreken wij de onderzoekspopulatie. Aansluitend wordt de empirische analyse gepresenteerd, worden enkele 'best practices' getoond en ronden wij af met een aantal conclusies.

\section{Globale beschrijiving IFRS 9 Financial Instruments}

De International Accounting Standards Board (IASB) heeft op 24 juli 2014 IFRS 9 'Financiële instrumenten' gepubliceerd als vervanger van de oude standaard over financiële instrumenten, IAS 39. Deze standaard geeft onder andere nieuwe regels voor de Classificatie en waardering van financiële activa en financiële verplichtingen. Met deze standaard wil de IASB ervoor zorgen dat de standaard voor financiële instrumenten minder complex 
wordt $^{1}$, dat kredietverliezen eerder worden genomen ${ }^{2}$, dat het aantal impairmentmodellen wordt verminderd tot één algemeen impairmentmodel en dat het probleem van het eigen kredietrisico bij waardering van financiële verplichtingen tegen reële waarde wordt opgelost. ${ }^{3}$

IFRS 9 onderkent drie onderdelen:

1. Classificatie en waardering;

2. Bijzondere waardevermindering;

3. Hedge accounting.

\subsection{Classificatie en waardering}

Bij de eerste verwerking wordt een financieel actief geclassificeerd in één van de drie waarderingscategorieën:

A. Geamortiseerde kostprijs (AC, 'Amortised Cost');

B. Reële waarde met waardeveranderingen in het eigen vermogen (FVOCI, 'Fair Value through Other Comprehensive Income');

C. Reële waarde met waardeveranderingen in de winst-en-verliesrekening (FVTPL, 'Fair Value through Profit or Loss').

De eerste waardering van financiële instrumenten gebeurt tegen reële waarde, gecorrigeerd voor transactiekosten met uitzondering van de categorie FVTPL waar de transactiekosten direct in de winst-en-verliesrekening worden opgenomen. $\mathrm{Na}$ de eerste waardering worden de financiële instrumenten gewaardeerd op basis van de hiervoor beschreven waarderingscategorieën.

\section{Vreemdvermogensinstrumenten: twee toetsen}

Bij het rubriceren en waarderen van ieder financieel actief dat een vreemdvermogensinstrument is, dienen ondernemingen deze financiële activa te onderwerpen aan twee toetsen, een businessmodeltoets en een kasstroomkenmerkentoets (ook wel de SPPI-toets genoemd. SPPI staat voor 'Solely Payments of Principal and Interest'). Zakt het financieel actief voor één van deze twee toetsen, dan is vervolgwaardering tegen reële waarde verplicht.

De businessmodeltoets is nodig om te bepalen of een financieel actief dat voldoet aan de SPPI-toets dient te worden gerubriceerd en gewaardeerd tegen geamortiseerde kostprijs (AC) of tegen reële waarde met waardeveranderingen in het eigen vermogen (FVOCI).

\section{Businessmodeltoets}

Met 'Businessmodel' wordt bedoeld de wijze waarop een onderneming haar financiële activa beheert om kasstromen daaruit te genereren. Dit kan door het genereren van kasstromen door de ontvangst van alleen de contractuele kasstromen van rente en hoofdsom (HTC, held to collect), door zowel het genereren van contractuele kasstromen als door de verkoop van het instrument (HTC\&S, held to collect and sell) of door andere businessmodellen toe te passen. In het laatste geval kan worden gedacht aan het aanhouden van financiële activa voor handelsdoeleinden of het maximaliseren van kasstromen door middel van verkoop. In het eerste geval wordt tegen AC gewaardeerd, in het tweede geval tegen FVOCI, terwijl bij de andere businessmodellen wordt gewaardeerd tegen FVTPL. Bij waardering tegen FVOCI is de verwerking in de winst-en-verliesrekening identiek aan die voor AC-posten (incl. het Expected Credit Loss (ECL) impairmentmodel), waarbij de (overige) wijzigingen in fair value (FV) gedurende de looptijd in other comprehensive income (OCI) komen. Aan het einde van de looptijd worden deze wijzigingen alsnog in winst-en-verliesrekening verwerkt (recycling).

Ondernemingen hebben ook de mogelijkheid om vreemdvermogensinstrumenten die normaal gesproken tegen AC of tegen FVOCI worden gewaardeerd, te waarderen tegen FVTPL onder de voorwaarde dat hierdoor een accounting mismatch wordt verminderd.

\section{SPPI-toets}

Met de term 'SPPI' wordt bedoeld dat de contractuele bepalingen van het financieel instrument alleen kasstromen betreffen die uitsluitend reguliere rente en terugbetaling van de hoofdsom bevatten. In dat geval zijn de contractuele kasstromen te beschouwen als kasstromen uit een basisleenovereenkomst. De hoofdsom is in dit kader gedefinieerd als de reële waarde van het financieel actief bij eerste verwerking. De hoofdsom kan veranderen gedurende de tijd, bijvoorbeeld als gevolg van terugbetalingen op de hoofdsom. Rente is het bedrag van de tijdswaarde van geld en kredietrisico. Rente kan daarnaast bestaan uit bedragen voor vergoeding voor andere basisleenrisico's en uit vergoeding voor kosten en winstmarge.

Voldoet een financieel actief niet aan de SPPI-toets, dan wordt het financieel actief gewaardeerd tegen FVTPL.

Schematisch is dit uitgewerkt in figuur 1 (rechtergedeelte voor vreemdvermogensinstrumenten).

\section{Eigenvermogensinstrumenten}

Eigenvermogensinstrumenten worden in beginsel tegen FVTPL gewaardeerd, tenzij de onderneming ervoor kiest om op instrumentbasis deze tegen FVOCI (FVOCI-optie) te waarderen. Bij het waarderen tegen FVOCI vindt geen recycling plaats bij latere verkoop. Alleen dividenden worden in de winst-en-verliesrekening verwerkt. Voorwaarde is wel dat deze instrumenten geen onderdeel mogen zijn van de handelsportefeuille. De keuze wordt per instrument gemaakt bij de eerste opname op de balans en is onherroepelijk. Zie figuur 1 (linkergedeelte voor eigenvermogensinstrumenten).

\section{Derivaten}

Derivaten moeten op basis van IFRS 9, net als onder IAS 39, tegen FVTPL worden verwerkt.

De andere afkortingen zijn hiervoor al in de tekst uitgelegd. 
Figuur 1. Schematische uitwerking van het onderdeel classificatie en waardering van financiële activa onder IFRS 9. Met 'BM' in figuur 1 wordt bedoeld, 'business model'.

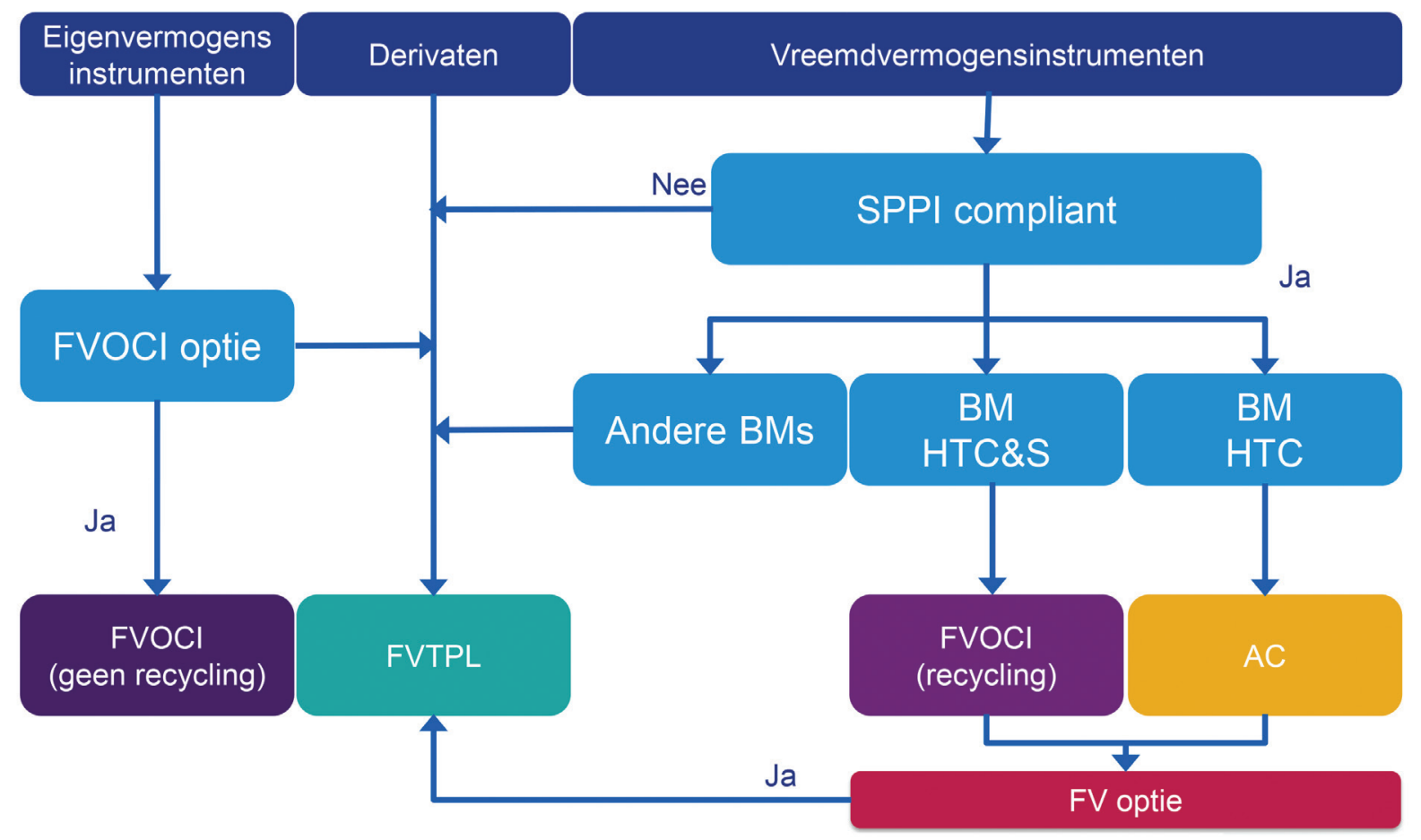

\section{Financiële verplichtingen}

Financiële verplichtingen worden doorgaans tegen $\mathrm{AC}$ gewaardeerd. ${ }^{4}$ Ondernemingen mogen ook kiezen om financiële verplichtingen die normaal gesproken tegen AC worden gewaardeerd, te waarderen tegen FVTPL onder de voorwaarde dat hierdoor een accounting mismatch wordt verminderd. ${ }^{5}$ Daarbij gaan de waardeveranderingen die betrekking hebben op het eigen kredietrisico naar het eigen vermogen in plaats van naar de winst-en-verliesrekening. Met een accounting mismatch wordt bedoeld een mismatch in het resultaat, veroorzaakt door een verschil in het moment van verwerken van de resultaten van de activa en passiva (verwerkingsmismatch) en/of door een waarderingsverschil tussen de activa en passiva (waarderingsmismatch).

\subsection{Bijzondere waardevermindering}

Onder IFRS 9 worden te verwachten kredietverliezen (expected credit losses of ECLs) in plaats van alleen opgelopen kredietverliezen (incurred credit losses) opgenomen in de boekwaarde van de financiële activa en in de winst-en-verliesrekening. Dit houdt in dat er zich nog geen objectieve aanwijzingen van verwachte oninbaarheid, een zogenaamd loss event, hoeft te hebben voorgedaan om een bijzondere waardevermindering uit hoofde van te verwachten kredietverliezen op te nemen. Direct al bij het opnemen van het financieel actief op de balans van de onderneming, wordt een voorziening voor te verwachten kredietverliezen (hierna bijzondere waardevermindering genoemd) gevormd. Dit is van toepassing op alle vreemdvermogensinstrumenten die tegen $\mathrm{AC}$ of tegen FVOCI worden gewaardeerd, niet in de balans opgenomen toezeggingen en financiële garanties (tenzij deze op FVTPL worden gewaardeerd), alsmede op leasevorderingen en op contractactiva ('contract assets') onder IFRS 15.

IFRS 9 kent een algemene benadering voor het waarderen van bijzondere waardeverminderingen. Onder deze benadering worden kredietverliezen gebaseerd op:

- 12-maands ECLs - dit wordt gedefinieerd als het deel van de te verwachten kredietverliezen over de gehele verwachte looptijd die voortvloeien uit alle mogelijke default events die zich binnen 12 maanden na de balansdatum voordoen;

- Life-time ECLs - dit wordt gedefinieerd als de te verwachten kredietverliezen die voortvloeien uit alle mogelijke default events over de gehele verwachte looptijd van het financieel instrument.

Vanaf het moment van opname in de balans wordt de bijzondere waardevermindering op financiële activa gebaseerd op de 12-maands ECLs, totdat sprake is van een significante toename van het kredietrisico sinds het moment dat het financieel actief in de boeken is opgenomen. Op het moment van deze toename worden bijzondere waardeverminderingen gebaseerd op life-time ECLs.

Het vormen van een bijzondere waardevermindering voor te verwachten kredietverliezen wordt vervolgens 
gedaan op basis van fases, waarbij fase 1 is gebaseerd op de 12-maands ECLs en fase 2 en 3 op de life-time ECLs. ${ }^{6}$ Voor corporates wordt met name een toename in de bijzondere waardevermindering voor kredietverliezen verwacht vanwege het toevoegen van de te verwachten kredietverliezen.

Voor handelsdebiteuren, lease-vorderingen uit IAS 17/ IFRS 16 en contractactiva uit IFRS 15 biedt IFRS 9 ook een vereenvoudigde benadering. Deze vereenvoudigde benadering is niet altijd optioneel. Voor handelsdebiteuren en contractactiva onder IFRS 15 zonder 'significante financieringscomponent' is deze benadering verplicht (zie IFRS 9.5.5.15(a)(i)) en ook figuur 2). Onder deze benadering worden bijzondere waardeverminderingen voor te verwachten kredietverliezen direct al gebaseerd op de life time ECLs in plaats van op de 12-maands ECLs.

Figuur 2. Schematische verwerking van bijzondere waardeverminderingen.

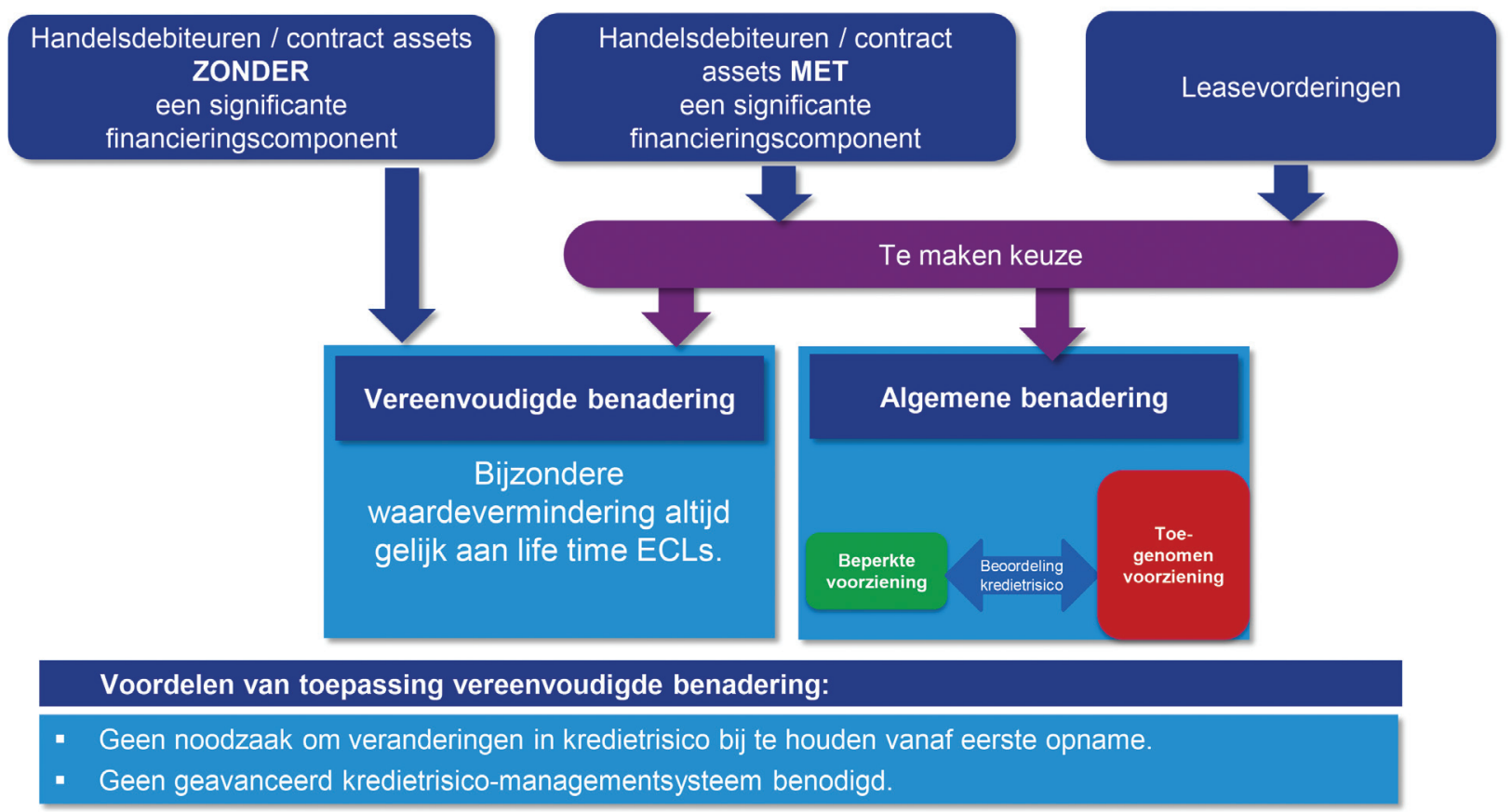

\subsection{Hedge accounting}

Hedge accounting is optioneel. Corporates hebben bij toepassing van hedge accounting de keuze om hedge accounting toe te passen onder IFRS 9 (algemeen hedge-accountingmodel), dan wel om hedge accounting nog toe te passen op basis van IAS 39 (dit laatste is mogelijk totdat het IASB-project voor de verwerking van dynamic risk management (macrohedging) is afgerond).

Het nieuwe hedge-accountingmodel van IFRS 9 beoogt beter aan te sluiten op het risicomanagementsysteem van corporates. Daardoor bestaat een betere link tussen de verwerking van hedge accounting en het risicomanagement van de corporate. Indien de verhouding tussen de afgedekte positie en de daarvoor gebruikte hedge-instrumenten wijzigt, wordt rebalancing toegepast om hiermee aansluiting te houden met het risicomanagement van de onderneming. De harde grenzen, waarbuiten de hedgerelatie wordt verbroken (de 80-125\%-regel), zijn vervallen.
Wel geldt onder IFRS 9 dat de hedgerelatie niet vrijwillig mag worden verbroken en een nieuwe hedgerelatie mag worden opgezet, zolang de economische hedgerelatie nog bestaat.

IFRS 9 biedt ook mogelijkheden om meer soorten afgedekte posities voor hedge accounting in aanmerking te laten komen, zoals risicocomponenten van niet-financiële activa (bijvoorbeeld de aluminium-component van een bierblikje in plaats van alle risicocomponenten van dit niet-financieel actief) en het combineren van niet-derivatenposities en derivaten tot een enkelvoudige, af te dekken positie (de zogenaamde aggregated exposure). Ook biedt IFRS 9 verbeteringen voor wat betreft de 'Costs of hedging'?

\subsection{Eerste toepassing van IFRS 9}

IFRS 9 kent voor de eerste toepassing bij overgang vanuit IAS 39 een aantal keuzes/transitiebepalingen: 
- Vrijstelling voor het opstellen van vergelijkende cijfers op basis van IFRS 9 voor classificatie en waardering en te verwachten kredietverliezen, maar niet voor toepassing van de Cost of hedging-benadering bij hedge accounting. De onderdelen 1) classificatie en waardering en 2) bijzondere waardevermindering worden retrospectief toegepast en onderdeel 3) hedge accounting wordt prospectief toegepast. Hierop is een uitzondering van toepassing voor cost of hedging, dat retrospectief moet worden toegepast voor de tijdswaarde van opties, indien onder IAS 39 alleen de intrinsieke waarde was aangewezen als hedge-instrument, en mag worden toegepast voor de termijnpunten van termijncontracten en voor vreemdevalutabasis-spreads van cross currency swaps, indien onder IAS 39 deze elementen zijn uitgesloten van de hedgerelatie;

- Bij de classificatie en waardering van vreemdvermogensinstrumenten onder de financiële activa mag de analyse van het businessmodel plaatsvinden op de datum van eerste toepassing van IFRS 9, dus op 1 januari 2018 of op de datum van eerdere toepassing;

- De toewijzingen van de fair value-optie van financiële activa en financiële verplichtingen mogen worden gedaan op het moment van eerste toepassing van IFRS 9. Hierdoor kunnen in het verleden onder IAS 39 gedane toewijzingen van de fair value-optie ongedaan worden gemaakt.

\subsection{Verschillen met oude regelgeving}

Belangrijke verschillen tussen oude regelgeving (IAS 39) en nieuwe regelgeving (IFRS 9) zijn:

- IFRS 9 kent niet de categorieën die IAS 39 kende. IFRS 9 classificeert en waardeert financiële activa op basis van twee toetsen, de SPPI-toets en de businessmodeltoets. Een gevolg is dat niet langer afzonderli$\mathrm{jk}$ hoeft te worden beoordeeld of in financiële activa embedded derivaten zijn begrepen;

- IFRS 9 is voor de classificatie en waardering van financiële verplichtingen gelijk aan IAS 39 met uitzondering van de verwerking van het eigen kredietrisico bij waardering van financiële verplichtingen tegen reële waarde;

- IFRS 9 behandelt de verwerking van de aanpassing van de contante waarde van een financiële verplichting bij een non-substantial modification en een gewijzigde inschatting van de contractuele kasstromen op gelijke wijze (net als voor een financieel actief), met directe verwerking in de winst-en-verliesrekening, indien de wijziging voortvloeit uit een vaste component van de rente. Dit kan tot een aanpassing leiden bij transitie, vanwege de retrospectieve toepassing, doordat in het verleden onder IAS 39 bij een non-substantial modification het effect van de aanpassing werd geamortiseerd;

- IFRS 9 kent een expected credit loss-model, terwijl IAS 39 een incurred credit loss-model kent en IFRS 9 heeft één algemeen impairmentmodel, terwijl onder
IAS 39 meerdere impairmentmodellen bestaan;

- IFRS 9 biedt meer mogelijkheden om hedge accounting toe te passen, zoals risico-componenten van niet-financiële activa en aggregated exposures en bevat een praktische verwerkingswijze voor de kosten van hedging;

- De naar aanleiding van IFRS 9 aangepaste IFRS 7 Financial Instruments: Disclosures kent uitgebreidere toelichtingsvereisten.

\section{Globale beschrijiving IFRS 15 Revenue from Contracts with Customers}

IFRS 15 vervangt als nieuwe standaard voor omzetverantwoording IAS 11 Construction Contracts, IAS 18 Revenue en verschillende interpretaties. Met de nieuwe regelgeving wil de IASB zorgen voor een meer consistente omzetverantwoording, een betere vergelijkbaarheid tussen bedrijven en het verstrekken van meer informatie.

Het basisprincipe is dat een onderneming omzet verantwoordt voor de vergoeding waar de onderneming verwacht recht op te hebben in ruil voor het overdragen van producten of het verlenen van diensten aan een klant.

Het raamwerk dat de standaard biedt, omvat vijf stappen:

1. Identificeer het contract met de klant;

2. Identificeer de afzonderlijke prestatieverplichtingen in het contract;

3. Bepaal de transactieprijs;

4. Alloceer de transactieprijs aan de afzonderlijke prestatieverplichtingen; en

5. Verantwoord omzet wanneer aan een prestatieverplichting is voldaan.

\section{Stap 1 Identificeer het contract}

Contracten met klanten die afdwingbare rechten en verplichtingen creëren, vallen binnen de reikwijdte van de standaard. IFRS 15 wordt toegepast op een individueel contract, tenzij meerdere contracten gecombineerd moeten worden tot één contract.

\section{Stap 2 Identificeer de prestatieverplichtingen}

IFRS 15 stelt dat omzet verantwoord moet worden als de onderneming aan een prestatieverplichting voldoet. Een prestatieverplichting is een toezegging tot levering aan een klant van (a) een product of dienst (of een bundel van producten of diensten) die onderscheidend zijn of (b) een serie van onderscheidende producten of diensten die substantieel hetzelfde zijn en op dezelfde wijze aan de klant geleverd worden. Een contract kan meerdere prestatieverplichtingen omvatten, bijvoorbeeld het leveren van een machine en het uitvoeren van onderhoud aan die machine. In de praktijk is het vaststellen welke prestatieverplichtingen er binnen een contract onderscheiden moeten worden een grote uitdaging. 


\section{Stap 3 Bepaal de transactieprijs}

De transactieprijs is de vergoeding waar de onderneming verwacht recht op te hebben in ruil voor het leveren van producten of diensten aan de klant, exclusief het bedrag dat wordt ontvangen namens andere partijen (bijvoorbeeld BTW). De bepaling van de transactieprijs kan complex zijn, omdat rekening moet worden gehouden met variabele vergoedingen, significante financieringscomponenten, vergoedingen in natura en vergoedingen die aan de klant betaald worden.

Stap 4 Alloceer de transactieprijs aan de prestatieverplichtingen

In stap 4 wordt de in stap 3 bepaalde transactieprijs toegerekend aan de in stap 2 geïdentificeerde prestatieverplichtingen. Dus als de transactieprijs $€ 100$ is en het contract twee aparte prestatieverplichtingen omvat, wordt in deze stap bepaald hoe de $€ 100$ verdeeld moet worden over de twee prestatieverplichtingen. In het algemeen wordt de transactieprijs verdeeld op basis van de zelfstandige verkoopprijs van de individuele prestatieverplichtingen.

\section{Stap 5 Verantwoord de omzet}

De laatste stap is het verantwoorden van de omzet als de onderneming aan een specifieke prestatieverplichting heeft voldaan. In het algemeen wordt een product of dienst als geleverd beschouwd als de klant de beschikkingsmacht over het product of de dienst verkregen heeft. Beschikkingsmacht verwijst daarbij naar de mogelijkheid om het gebruik te bepalen en substantieel alle voordelen te verkrijgen. Dit wijkt af van de "risk \& rewards"-benadering onder de oude regelgeving.

Het overdragen van de beschikkingsmacht kan plaatsvinden op één moment of gedurende een periode. Dit bepaalt of de omzet op één moment of gedurende een periode verantwoord moet worden. Er is sprake van het voldoen aan een prestatieverplichting gedurende een periode als:

1. De klant de voordelen consumeert gelijktijdig met de werkzaamheden van de onderneming (bijvoorbeeld schoonmaakdiensten);

2. De onderneming producten of diensten levert waar de klant de beschikkingsmacht over krijgt gedurende het ontstaan of de verbetering van het product (bijvoorbeeld onderhoud aan een gebouw dat in eigendom is van de klant); of

3. De onderneming een product makt of een dienst levert die niet op een andere manier gebruikt kan worden door de onderneming en de onderneming een afdwingbaar recht heeft op betaling voor de werkzaamheden die reeds zijn verricht.

\section{Andere aandachtspunten}

In de praktijk komt het regelmatig voor dat contracten aangepast worden. IFRS 15 geeft regels om vast te stellen of de aanpassing leidt tot een nieuw contract. Als een aanpassing niet leidt tot een nieuw contract, is de verwerking afhankelijk van de vraag of nog te leveren producten en diensten onderscheidend zijn van de producten en diensten die reeds geleverd zijn op het moment van de contractwijziging.

De omzetverantwoording kan in een andere periode plaatsvinden dan de periode waarin uitgaven gedaan worden die nodig zijn om aan het contract te voldoen. Als aan bepaalde voorwaarden is voldaan, worden deze uitgaven geactiveerd, zodat er matching tussen de kosten en omzet ontstaat. Kosten die gemaakt zijn om een contract te verkrijgen moeten onder bepaalde voorwaarden ook worden geactiveerd en afgeschreven. Verschillen tussen de momenten van omzetverantwoording, ontvangsten en het ontstaan van onvoorwaardelijke rechten op een vergoeding kunnen daarnaast leiden tot contractactiva en contractverplichtingen in de balans.

IFRS 15 bevat ook specifieke bepalingen voor onder andere de verwerking van retouren, opties voor klanten, terugkoopverplichtingen, licenties en garanties. De standaard bevat tevens regels om de informatieverstrekking over omzetverantwoording te verbeteren.

\section{Eerste toepassing}

IFRS 15 biedt twee verwerkingswijzen voor de eerste toepassing van IFRS 15 . Bij de "volledig retrospectieve verwerking" wordt, in lijn met IAS 8, de jaarrekening opgesteld alsof IFRS 15 altijd van toepassing is geweest. Dat betekent dat IFRS 15 ook voor de vergelijkende cijfers toegepast moet worden. Bij de "aangepaste retrospectieve verwerking" worden de cijfers van het jaar van eerste verwerking wel op basis van IFRS 15 opgesteld, maar de vergelijkende cijfers niet. In de toelichting moet dan wel voor het huidige jaar de cijfers op basis van de oude standaarden getoond worden om een goed inzicht te geven in de impact van de toepassing van IFRS 15 . Bij beide methoden kunnen bepaalde vereenvoudigingen (practical expedients) toegepast worden om de eerste toepassing gemakkelijker te maken.

\section{Verschillen met oude regelgeving}

Belangrijke verschillen tussen de oude en nieuwe regelgeving zijn:

- IFRS 15 geeft duidelijker aan dat contracten ook gebaseerd kunnen zijn op mondelinge afspraken of impliciete overeenkomsten;

- IFRS 15 geeft duidelijker richtlijnen voor het combineren van contracten, het verwerken van contractaanpassingen en het verwerken van contracten met meerdere prestatieverplichtingen;

- IFRS 15 kan leiden tot het identificeren van andere prestatieverplichtingen;

- Onder IFRS 15 is de transactieprijs gebaseerd op de verwachte ontvangsten waardoor variabele vergoedingen mogelijk eerder verantwoord worden;

- IFRS 15 geeft duidelijker richtlijnen voor de verwerking van variabele vergoedingen; 
- IFRS 15 introduceert met het concept 'zelfstandige verkoopprijs' een nieuwe methode om de transactieprijs te alloceren aan de prestatieverplichtingen;

- Onder IFRS 15 is het moment van omzetverantwoording gebaseerd op het verkrijgen van beschikkingsmacht door de klant in plaats van het overdragen van risks \& rewards;

- IFRS 15 biedt meer richtlijnen hoe voortgang gemeten moet worden bij omzetverantwoording gedurende een periode;

- Onder IFRS 15 is bij de analyse of een onderneming acteert als agent of principaal leidend of de entiteit beschikkingsmacht heeft verkregen over het goed of de dienst voordat deze aan de klant geleverd is. Daarom is kredietrisico vervallen als indicator dat een onderneming acteert als principaal; en

- IFRS 15 heeft aanvullende eisen qua toelichting.

\section{Toelichtingsvereisten voor komende regelgeving}

Het is voor gebruikers van de jaarrekening nuttig om te weten wat de impact van toekomstige regelgeving is. Als een aandelenanalist bijvoorbeeld een voorspelling doet over de omzet of de winst in komende jaren, is het belangrijk dat daarbij rekening wordt gehouden met wijzigingen in standaarden. Daarnaast kunnen publicaties van (half)jaarcijfers in een jaar met belangrijke wijzigingen in de regelgeving, sneller en beter geïnterpreteerd worden als de verwachte impact van de wijzigingen al eerder gecommuniceerd is. Daarom kent IAS 8 de bepaling dat als een onderneming nieuwe regelgeving nog niet toegepast heeft, omdat toepassing nog niet verplicht is, de onderneming dat moet vermelden. Daarnaast moet de onderneming bekende of redelijk in te schatten informatie verstrekken die relevant is voor het beoordelen van de mogelijke impact van de nieuwe standaard op de jaarrekening in het eerste jaar van toepassing (IAS 8.30).

$\mathrm{Bij}$ het toepassen van bovengenoemde bepaling moet een onderneming op basis van IAS 8.31 in overweging nemen om het volgende toe te lichten:

- De naam van de nieuwe standaard;

- De aard van de veranderingen;

- De datum waarop de nieuwe standaard uiterlijk toegepast moet worden;

- De datum waarop de onderneming de nieuwe standaard wil toepassen; en

- (a) Een bespreking van de impact die de eerste toepassing van de standaard naar verwachting zal hebben op de jaarrekening; of

(b) als de impact niet bekend of redelijkerwijs te schatten is, een opmerking daarover.

De European Securities and Markets Authority (ESMA) heeft ook benadrukt dat het verstrekken van bovengenoemde informatie belangrijk is. In een publicatie van 20 juli 2016 over IFRS 15 (ESMA 2016a) geeft ESMA aan dat het doel van de IAS 8-bepalingen is om gebruikers in staat te stellen om de effecten van de toekomstige toepassing van nieuwe standaarden op de financiële positie en prestaties van de onderneming van te voren te begrijpen. Hoewel de timing van de toelichting kan variëren afhankelijk van complexiteit van het implementatieproces, de verwachte impact en de benodigde aanpassingen in de informatiesystemen, heeft ESMA in die publicatie aangegeven dat zij verwacht dat in de 2017-jaarrekening een kwantitatieve analyse gegeven wordt van de impact van IFRS 15. Een soortgelijke publicatie, maar dan voor IFRS 9, is gepubliceerd op 10 november 2016 (ESMA 2016b). Uit een onderzoek van ESMA naar deze toelichtingen in de jaarrekeningen 2016 en de halfjaarberichten $2017^{8}$ komt namelijk naar voren dat deze toelichtingen verder kunnen worden verbeterd. In een publicatie van 27 oktober 2017 (ESMA 2017b) heeft ESMA herhaald dat één van de prioriteiten voor beursgenoteerde ondernemingen is de toelichting over de verwachte impact van de overgang naar nieuwe standaarden. ESMA vindt dat beursgenoteerde ondernemingen zich moeten focussen op de nieuwe IFRSs in hun 2017 IFRS-jaarrekeningen. ${ }^{9}$ ESMA geeft aan dat een uitgebreide toelichting van de verwachte impact mogelijk moet zijn, omdat de 2017-jaarrekeningen worden gepubliceerd nadat IFRS 9 en 15 al van toepassing zijn.

\section{Beschrijving onderzoekspopulatie}

Uitgangspunt voor het onderzoek zijn de ondernemingen die opgenomen zijn in de FTSE Russel Eurotop 100 index ${ }^{10}$ exclusief 26 financiële instellingen. Financiële instellingen zijn niet opgenomen in dit onderzoek, omdat de impact van IFRS 9 op financiële instellingen in een ander artikel in deze editie wordt onderzocht. Verder raakt IFRS 15 deze ondernemingen maar beperkt. Ondernemingen die US GAAP toepassen worden ook niet meegenomen evenals ondernemingen die IFRS 9 reeds in hun 2017-jaarrekening toepassen. De onderzoekspopulatie bestaat uit 70 ondernemingen voor IFRS 9 en 72 entiteiten voor IFRS 15 - zie tabel 1 .

In de bijlage van dit artikel is een overzicht opgenomen van de onderzochte jaarrekeningen. Daaruit blijkt ook welke ondernemingen IFRS 9 eerder toepassen.

Tabel 2 toont de onderzochte ondernemingen per bedrijfstak en tabel 3 per land. Consumer Goods is de grootste bedrijfstak in dit onderzoek. Bijna $70 \%$ van de entiteiten komt uit Duitsland, Frankrijk of Verenigd Koninkrijk. Ongeveer $85 \%$ van de onderzochte jaarrekeningen heeft als balansdatum 31 december 2017. Voor ongeveer $11 \%$ van de ondernemingen is een jaarrekening met eerdere balansdatum gebruikt. De resterende $4 \%$ heeft een balansdatum na 31 december 2017. 
Tabel 1. Selectie onderzoekspopulatie.

\begin{tabular}{lcc} 
& IFRS 9 & IFRS $\mathbf{1 5}$ \\
FTSE Eurotop 100 & 100 & 100 \\
Financiële instellingen & -26 & -26 \\
Toepassing US GAAP & -2 & -2 \\
Vervroegde toepassing standaard & -2 & 0 \\
Onderzoekspopulatie & 70 & 72 \\
\hline
\end{tabular}

Tabel 2. Onderzoekspopulatie per bedrijfstak.

\begin{tabular}{|c|c|c|c|c|}
\hline & \multicolumn{2}{|c|}{ IFRS 9} & \multicolumn{2}{|c|}{ IFRS 15} \\
\hline Bedrijfstak & aantal & $\%$ & aantal & $\%$ \\
\hline Basic Materials & 8 & $11 \%$ & 8 & $11 \%$ \\
\hline Consumer Goods & 23 & $33 \%$ & 23 & $32 \%$ \\
\hline Consumer Services & 4 & $6 \%$ & 4 & $6 \%$ \\
\hline Health Care & 9 & $13 \%$ & 9 & $13 \%$ \\
\hline Industrials & 7 & $10 \%$ & 9 & $13 \%$ \\
\hline Oil \& Gas & 5 & $7 \%$ & 5 & $7 \%$ \\
\hline Technology & 3 & $4 \%$ & 3 & $4 \%$ \\
\hline Telecommunications & 6 & $9 \%$ & 6 & $8 \%$ \\
\hline \multirow[t]{2}{*}{ Utilities } & 5 & $7 \%$ & 5 & $7 \%$ \\
\hline & 70 & $100 \%$ & 72 & $100 \%$ \\
\hline
\end{tabular}

Tabel 3. Onderzoekspopulatie per land.

\begin{tabular}{|c|c|c|c|c|}
\hline \multicolumn{3}{|c|}{ IFRS 9} & \multicolumn{2}{|c|}{ IFRS 15} \\
\hline Land & aantal & $\%$ & aantal & $\%$ \\
\hline België & 1 & $1 \%$ & 1 & $1 \%$ \\
\hline Denemarken & 1 & $1 \%$ & 2 & $3 \%$ \\
\hline Duitsland & 15 & $21 \%$ & 15 & $21 \%$ \\
\hline Finland & 1 & $1 \%$ & 1 & $1 \%$ \\
\hline Frankrijk & 16 & $23 \%$ & 17 & $24 \%$ \\
\hline Italië & 2 & $3 \%$ & 2 & $3 \%$ \\
\hline Nederland & 5 & $7 \%$ & 5 & $7 \%$ \\
\hline Noorwegen & 2 & $3 \%$ & 2 & $3 \%$ \\
\hline Spanje & 3 & $4 \%$ & 3 & $4 \%$ \\
\hline Verenigd Koninkrijk & 17 & $24 \%$ & 17 & $24 \%$ \\
\hline Zweden & 2 & $3 \%$ & 2 & $3 \%$ \\
\hline \multirow[t]{2}{*}{ Zwitserland } & 5 & $7 \%$ & 5 & $7 \%$ \\
\hline & 70 & $100 \%$ & 72 & $100 \%$ \\
\hline
\end{tabular}

\section{Empirische analyse IFRS 9}

\subsection{Belangrijkste vereisten toegelicht?}

Allereerst is gekeken of de toelichtingen over de aard van de veranderingen in de grondslagen zijn opgenomen. Zo blijkt dat $21 \%$ van de onderzochte ondernemingen deze toelichtingen voor de drie verschillende onderdelen van IFRS 9 heeft opgenomen. Bij de helft van de onderzochte ondernemingen worden alleen de verschillende onderdelen benoemd, zonder deze verder toe te lichten. Dit sluit aan bij onderzoek van ESMA van begin april 2018 (ESMA 2018), waarin wordt aangegeven dat $50 \%$ van de 53 onderzochte jaarrekeningen van corporates geen informatie dan wel slechts boilerplate en niet-specifieke informatie over de impact van IFRS 9 geeft. ${ }^{11}$ In $6 \%$ van de onderzochte ondernemingen wordt in het geheel geen informatie over de nieuwe vereisten gegeven. Het overige deel, $23 \%$ van de onderzochte ondernemingen, bevat slechts informatie over één of twee onderdelen door deze onderdelen toe te lichten dan wel slechts te benoemen. Het andere onderdeel of de andere onderdelen van IFRS 9 worden niet toegelicht of benoemd (zoals in hoofdstuk 2 aangegeven kent IFRS 9 drie onderdelen). Een reden voor het niet benoemen of toelichten van de verschillende onderdelen dan wel het slechts benoemen van één of twee van de drie onderdelen kan zijn dat deze onderdelen geen of beperkte invloed hebben op de (toekomstige) jaarrekeningen. 


\subsection{Impact bekend?}

Zoals in paragraaf 4 van dit artikel is aangegeven, verplicht IAS 8 ondernemingen om, indien bekend, de verwachte impact van komende standaarden te vermelden. ESMA heeft daarbij aangegeven dat zij verwacht dat ondernemingen in staat zijn om in de jaarrekening over 2017 aan te geven wat de impact van IFRS 9 en 15 zal zijn (ESMA 2016a, 2017a, 2018).

Uit tabel 4 blijkt dat minimaal $84 \%$ van de onderzochte ondernemingen heeft aangegeven dat de impact bekend is. 'Minimaal', omdat per onderdeel van IFRS 9 de analyse is uitgevoerd. Voor onderdeel 1) classificatie en waardering, 2) bijzondere waardevermindering en voor 3) hedge accounting zijn de percentages respectievelijk: $96 \%, 96 \%$ en $84 \%$. De categorie 'Impact bekend' houdt in dat de onderneming de impact bekend maakt, al dan niet kwantitatief. Tussen de $27-32 \%$ van de onderzochte ondernemingen heeft deze impact ook gekwantificeerd. Bij een deel van deze ondernemingen die de impact heeft gekwantificeerd is de impact niet materieel. Veelal is dit gedaan door een bedrag in de toelichting te noemen of aan te geven dat er geen effect is (nihil effect). In de categorie 'Impact niet gekwantificeerd', als onderdeel van de hoofdcategorie 'Impact bekend' hebben de ondernemingen aangegeven dat de impact van IFRS 9 niet materieel is. Hierdoor is de exacte impact minder relevant. In paragraaf 2.2 'Bijzondere waardevermindering' hebben we aangegeven dat voor dit onderdeel een toename in de bijzondere waardevermindering voor kredietverliezen wordt verwacht vanwege het toevoegen van te verwachten kredietverliezen. Zoals hiervoor is aangegeven is voor dit onderdeel de toename slechts in een deel van de gevallen materieel.

Een deel van de ondernemingen waarbij de impact bekend is, heeft aangegeven dat de precieze impact nog kan wijzigen. Hierbij worden voorbehouden gemaakt zoals:

- De verwachte impact is gebaseerd op een inschatting, de daadwerkelijke impact kan hiervan afwijken;
- Het gebruik maken van bandbreedtes waarbinnen de impact zich kan bevinden;

- De huidige effecten zijn gebaseerd op de op dit moment beschikbare informatie en kunnen onderhevig zijn aan veranderingen;

- De onderneming onderzoekt nog de mogelijke transitieopties. Hierdoor kan de daadwerkelijke impact afwijken van de verwachte impact;

- De aanpassing van de cijfers is complex bij overgang naar IFRS 9 en kan daardoor afwijken van de feitelijke situatie;

- Het effect van toepassing van IFRS 9 of van bepaalde onderdelen van IFRS 9 wordt nog onderzocht;

- Het effect van de toepassing van IFRS 9 heeft zich gericht op bepaalde afdelingen, zoals de Treasury afdeling, omdat de meeste financiële instrumenten door deze afdeling worden aangehouden.

Bij de ondernemingen waarbij de impact bekend is en de 'Impact gekwantificeerd' is, is de impact niet altijd exact vermeld, zoals blijkt uit de volgende omschrijvingen:

- Low double-digit million impact, low single-digit million Euro range of mid-single-digit million range in Euro's;

- "In the region of approximately EUR X mln.".

Bij drie ondernemingen in de categorie 'Impact niet bekend' is voor de onderdelen 'Classificatie en waardering' en 'Bijzondere waardevermindering' nog niet duidelijk of sprake is van een (materiële) impact. Eén van deze drie ondernemingen heeft aangegeven dat de impact mogelijk niet materieel is, maar dat dat nog nader moet worden onderzocht.

Voor het onderdeel 'Hedge accounting' hebben elf ondernemingen nog niet aangegeven of sprake is van een (materiële) impact. Van deze elf ondernemingen hebben drie ondernemingen wel een indicatie gegeven dat mogelijk geen sprake is van een materiële impact door aan te geven dat de hedgerelaties hetzelfde blijven onder IFRS 9.

Tabel 4. Toelichting impact van de verschillende onderdelen van IFRS 9.

\begin{tabular}{|c|c|c|c|c|c|c|c|c|c|}
\hline & \multicolumn{3}{|c|}{$\begin{array}{c}\text { Classificatie \& } \\
\text { waardering }\end{array}$} & \multicolumn{3}{|c|}{$\begin{array}{c}\text { Bijzondere } \\
\text { waardeverminderingen }\end{array}$} & \multicolumn{3}{|c|}{ Hedge accounting } \\
\hline & aantal & $\%$ & $\%$ totaal & aantal & $\%$ & $\%$ totaal & aantal & $\%$ & $\%$ totaal \\
\hline \multicolumn{10}{|l|}{ Impact bekend } \\
\hline Impact gekwantificeerd zonder voorbehoud & 18 & $27 \%$ & $26 \%$ & 11 & $16 \%$ & $16 \%$ & 16 & $27 \%$ & $23 \%$ \\
\hline Impact gekwantificeerd met voorbehoud & 4 & $6 \%$ & $6 \%$ & 10 & $15 \%$ & $14 \%$ & 3 & $5 \%$ & $4 \%$ \\
\hline \multirow[t]{2}{*}{ Impact niet gekwantificieerd } & 45 & $67 \%$ & $64 \%$ & 46 & $69 \%$ & $66 \%$ & 40 & $68 \%$ & $57 \%$ \\
\hline & 67 & $100 \%$ & $96 \%$ & 67 & $100 \%$ & $96 \%$ & 59 & $100 \%$ & $84 \%$ \\
\hline \multicolumn{10}{|l|}{ Impact niet bekend } \\
\hline Impact materieel & 0 & $0 \%$ & $0 \%$ & 0 & $0 \%$ & $0 \%$ & 0 & $0 \%$ & $0 \%$ \\
\hline \multirow[t]{2}{*}{ Niet bekend of impact materieel is } & 3 & $100 \%$ & $4 \%$ & 3 & $100 \%$ & $4 \%$ & 11 & $100 \%$ & $16 \%$ \\
\hline & 3 & $100 \%$ & $4 \%$ & 3 & $100 \%$ & $4 \%$ & 11 & $100 \%$ & $16 \%$ \\
\hline Totaal & 70 & & $100 \%$ & 70 & & $100 \%$ & 70 & & $100 \%$ \\
\hline
\end{tabular}




\subsection{Significante impact?}

Zoals uit tabel 5 blijkt, geeft bijna $9 \%$ van de onderzochte ondernemingen (6 van de 70 ondernemingen) aan dat sprake is van een materiële impact bij de transitie naar IFRS 9. Dit sluit aan bij eerder uitgevoerd onderzoek van KPMG (KPMG, juni 2018) ${ }^{12}$ dat overigens alleen op Nederlandse beursgenoteerde ondernemingen betrekking heeft. Om een indruk te geven van de impact, hebben we deze vergeleken met het eigen vermogen en met de winst voor belasting. Daarbij valt op dat de impact, afgezet tegen de winst voor belasting kan oplopen tot $11 \%$ van deze winst. Dit betekent niet dat de winst ieder jaar $11 \%$ hoger of lager zal zijn, omdat het om een eenmalig effect gaat. Bij het afzetten van de impact tegen het eigen vermogen is de impact van IFRS 9 kleiner dan
$1 \%{ }^{13}$ Omdat de effecten op de toekomstige perioden niet kwantitatief worden toegelicht, kan hieruit geen conclusie worden getrokken of sprake is van een materiële impact op termijn. De materiële impact heeft in die $9 \%$ betrekking op het onderdeel 'Classificatie en waardering' (door diverse redenen, zie ook paragraaf 6.4 'Verwachte wijzigingen') en op het onderdeel 'Bijzondere waardevermindering' (in de meeste gevallen een hogere bijzondere waardevermindering als gevolg van toepassing van het ECL-model). De impact op het onderdeel Hedge accounting wordt door deze ondernemingen niet als materieel beschouwd.

Per bedrijfstak is de verwachte impact ook gegeven. Daarbij valt op dat de impact zich beperkt tot de bedrijfstakken Consumer goods, Oil \& Gas en Utilities met de grootste impact in de bedrijfstak Oil \& Gas.

Tabel 5. Percentage ondernemingen die materiële impact verwacht van IFRS 9 per bedrijfstak.

\begin{tabular}{|c|c|c|c|}
\hline \multirow[b]{2}{*}{ Bedrijfstak } & \multirow{2}{*}{$\begin{array}{c}\text { Bedrijfstak } \\
\text { Aantal }\end{array}$} & \multicolumn{2}{|c|}{ Materiële impact } \\
\hline & & Aantal & $\%$ \\
\hline Basic Materials & 8 & 0 & $0 \%$ \\
\hline Consumer Goods & 23 & 3 & $13 \%$ \\
\hline Consumer Services & 4 & 0 & $0 \%$ \\
\hline Health Care & 9 & 0 & $0 \%$ \\
\hline Industrials & 7 & 0 & $0 \%$ \\
\hline Oil \& Gas & 5 & 2 & $40 \%$ \\
\hline Technology & 3 & 0 & $0 \%$ \\
\hline Telecommunications & 6 & 0 & $0 \%$ \\
\hline Utilities & 5 & 1 & $20 \%$ \\
\hline Totaal & 70 & 6 & $9 \%$ \\
\hline
\end{tabular}

\subsection{Verwachte wijzigingen?}

In geval de impact niet materieel of significant wordt geacht kunnen er wel wijzigingen optreden als gevolg van de veranderingen door IFRS 9 . We hebben daarbij alleen gekeken naar de wijzigingen in het onderdeel Classificatie en waardering en in het onderdeel Hedge accounting. Voor het onderdeel Bijzondere waardevermindering is de impact al beschreven in paragraaf 6.2. en het gaat daarbij om één soort wijziging, een hogere bijzondere waardevermindering (voor te verwachten kredietverliezen).

\section{Onderdeel Classificatie en waardering}

Zoals in paragraaf 2.1 aangegeven worden financiële activa op basis van twee toetsen, de SPPI-toets en de businessmodeltoets, geclassificeerd en gewaardeerd. 17 ondernemingen ( $24 \%$ van de onderzochte ondernemingen) geven aan dat er wijzigingen zijn te verwachten in de classificatie van financiële activa, zoals kan worden afgeleid uit tabel 6 . De meest voorkomende wijzigingen zijn de herclassificaties van de categorie AC naar de categorie FVTPL en van de categorie AFS, 'available for sale' naar de categorie AC.

Bij de classificatie en waardering van financiële verplichtingen hebben we ons beperkt tot de andere verwerkingswijze van het eigen kredietrisico bij de waardering van financiële verplichtingen tegen FVTPL. Onder IFRS
9 worden deze waardeveranderingen uit hoofde van het eigen kredietrisico verwerkt in het eigen vermogen in plaats van in de winst-en-verliesrekening. Dit geldt voor twee ondernemingen.

Bij securitisaties of factoring worden veelal financiële activa, of het recht om kasstromen te genereren door de ontvangst van alleen de contractuele kasstromen, overgedragen aan een andere partij. Dit betekent dat deze financiële activa, waarbij de onderneming de intentie heeft om deze onmiddellijk of in de nabije toekomst te verkopen en deze instrumenten van de balans gaan, veelal als other business models worden gerubriceerd en tegen FVTPL worden gewaardeerd. Indien de financiële activa echter op de balans blijven, is het wel mogelijk dat aan het businessmodel van Held to collect wordt voldaan. Hiervoor is een nadere analyse nodig om daadwerkelijk te concluderen dat deze onder het businessmodel van Held to collect vallen.

Bij twee ondernemingen (deze twee ondernemingen zitten ook al in het aantal van 17 ondernemingen dat hiervoor is genoemd) wordt toegelicht dat sprake is van factoring, waardoor de classificatie en waardering van deze vorderingen wordt aangepast van AC naar FVTPL.

Verder is onderzocht of bij financiële verplichtingen is vermeld dat bij non-substantial modifications wijzigingen die optreden in de waardering van deze financiele verplichtingen direct in de winst-en-verliesrekening 
worden verwerkt. Bij een aanpassing van de geamortiseeerde kostprijs van financiële verplichtingen die zijn gewaardeerd tegen $\mathrm{AC}$ wordt de nieuwe, geamortiseerde kostprijs bepaald op basis van de nieuwe kasstromen contant gemaakt tegen de oorspronkelijke effectieve rentevoet. Onder IAS 39 werd het verschil tussen de oude en nieuw berekende $\mathrm{AC}$ niet direct in het resultaat verantwoord bij een non-substantial modification (een aanpassing van het contract als gevolg van heronderhandeling tussen bestaande geldgever en geldnemer die NIET leidt tot verwijdering uit de balans (derecognition)). De waardeverschillen werden geamortiseerd over de resterende looptijd van de financiële verplichting. Onder IFRS 9 worden ook bij een non-substantial modification deze waardeverschillen direct in het resultaat geboekt. Zoals uit tabel 6 blijkt hebben slechts twee ondernemingen toegelicht dat er niet-materiële wijzigingen zijn door deze non-substantial modification. Daarnaast heeft één onderneming vermeld dat financiële verplichtingen vóór 31 december 2017 zijn vervallen (extinguishments), waardoor er geen effect is bij transitie naar IFRS 9.

Corporates beleggen vaak overtollige geldmiddelen in geldmarktfondsen of andere beleggingsfondsen. Bij deze geldmarktfondsen of andere beleggingsfondsen hebben de houders daarvan, de beleggers, veelal een recht om deze beleggingen terug te verkopen aan deze fondsen, of anders gezegd de corporates hebben een zogenaamde putoptie. Daardoor is bij deze instrumenten met een putoptie sprake van puttable instrumenten. Deze puttable instrumenten voldoen niet aan de definitie van eigenvermogensinstrumenten uit IAS 32 Financial Instruments: Presentation, maar aan de definitie van vreemdvermogensinstrumenten. Het beoordelen van puttable instrumenten op basis van de definities uit IAS 32 is vereist voor het onderscheid in vreemdvermogensinstrumenten en eigenvermogensinstrumenten onder IFRS 9. Het gevolg hiervan is dat deze instrumenten als vreemdvermogensinstrumenten worden aangemerkt en, omdat ze niet aan de SPPI-toets voldoen, tegen FVTPL moeten worden gewaardeerd. Onder IAS 39 zouden deze instrumenten veelal als Available for Sale kunnen worden gerubriceerd, waarbij de waardeveranderingen in het eigen vermogen worden verwerkt tot aan de verkoop. Bij verkoop of bij eerdere impairment worden de waardeveranderingen in de winst-en-verliesrekening verwerkt (recycling). Het tegen FVTPL waarderen van deze beleggingen was ook mogelijk onder IAS 39. Bij zes ondernemingen is in een toelichting opgenomen dat sprake is van deze puttable instruments en dat hieruit een verwachte wijziging voortvloeit.

Tabel 6. Verwachte wijzigingen bij onderdeel Classificatie en waardering.

\begin{tabular}{lcc} 
& Aantal ondernemingen dat aanpassing genoemd heeft \\
Verwachte wijzigingen & Aantal & $\%$ \\
Andere classificatie van financiële activa & 17 & $24 \%$ \\
Verwerking eigen kredietrisico (in eigen vermogen) & 2 & $3 \%$ \\
Securitisatie/factoring & 2 & $3 \%$ \\
Non-substantial modification & 2 & $3 \%$ \\
Verwerking van beleggingen in puttable instrumenten & 6 & $9 \%$ \\
& & 9 \\
Totaal aantal ondernemingen & 70 & \\
\hline
\end{tabular}

\section{Onderdeel Hedge accounting}

Bij het onderdeel hedge accounting moet de cost of hedging voor de tijdswaarde bij opties retrospectief worden verwerkt en voor forward-elementen van termijncontracten en voor vreemdevalutabasis-spreads van cross currency swaps mag deze retrospectief worden verwerkt - zie daartoe paragraaf 2.4 'Eerste toepassing van IFRS 9'. In tabel 7 zijn de resultaten hiervan opgenomen per bedrijfstak. Daarbij valt op dat in $26 \%$ van de onderzochte ondernemingen de impact van de cost of hedging wordt toegelicht en dat deze retrospectief moet worden verwerkt. Voor wat betreft de impact op de bedrijfstakken valt het hoge percentage op voor de bedrijfstak Technology (67\% van de ondernemingen die cost of hedging toelichten), gevolgd door Utilities (40\%) en Consumer Goods (35\%).

Tabel 7. Retrospectieve verwerking Cost of hedging.

\begin{tabular}{lccc} 
Bedrijfstak & Bedrijfstak & Impact & \\
Aantal & Aantal & 0 & $0 \%$ \\
Basic Materials & 8 & 8 & $35 \%$ \\
Consumer Goods & 23 & 0 & $0 \%$ \\
Consumer Services & 4 & 3 & $33 \%$ \\
Health Care & 9 & 1 & $14 \%$ \\
Industrials & 7 & 1 & $20 \%$ \\
Oil \& Gas & 5 & 2 & $67 \%$ \\
Technology & 3 & 1 & $17 \%$ \\
Telecommunications & 6 & 2 & $40 \%$ \\
Utilities & 5 & $\mathbf{1 8}$ & $\mathbf{2 6 \%}$ \\
Totaal & $\mathbf{7 0}$ & & \\
\hline
\end{tabular}




\subsection{Transitiemethode?}

Bij de overgang naar IFRS 9 kan gebruik worden gemakt van een aantal transitiebepalingen, zoals beschreven in paragraaf 2.4 'Eerste toepassing van IFRS 9'. Deze hebben we opgenomen in tabel 8 .

Vrijstelling aanpassing vergelijkende cijfers

Voor wat betreft de vrijstelling voor het niet hoeven aanpassen van de vergelijkende cijfers heeft $47 \%$ van de onderzochte ondernemingen toegelicht dat zij hiervan gebruik maakt. Daarentegen zijn de andere transitiebepalingen (toepassen hedge accounting met terugwerkende kracht voor de cost of hedging, onderzoek businessmodel op datum van eerste toepassing, het aanwijzen en intrekken van eerdere aanwijzingen van financiële activa en financiële verplichtingen als FVTPL en FVOCI, toelichting dat gebruik is gemaakt van de vereenvoudigde benadering) veel minder toegelicht. De percentages zijn 26\%, 1\%, 3\%, $1 \%$ en $26 \%$ ). In de bedrijfstakken Technology, Industrials en Health Care zitten relatief de meeste ondernemingen die deze toelichtingen opnemen, zoals uit tabel 8 blijkt.

Tabel 8. Toelichtingen gekozen transitiemethoden per bedrijfstak.

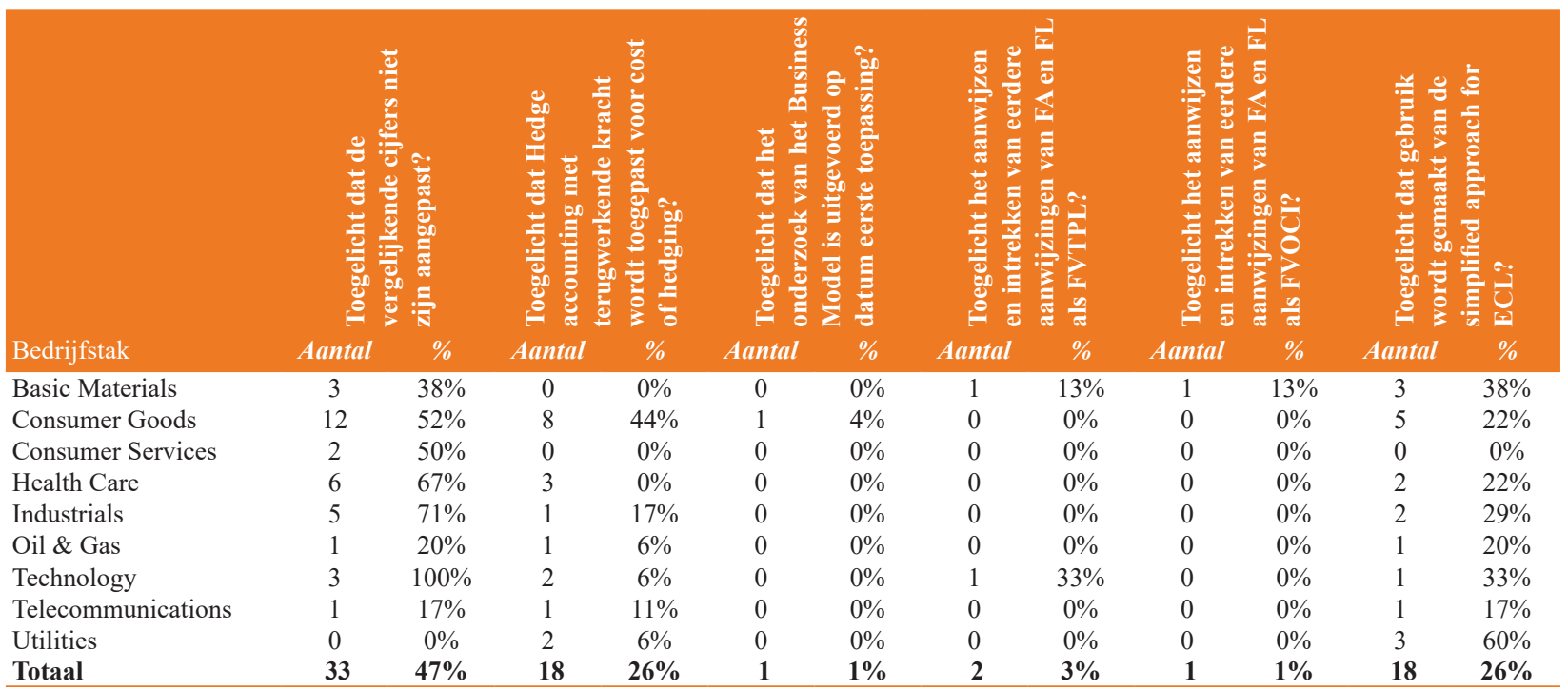

6.6 Aandacht in bestuursverslag en controleverklaring?

Geen van de ondernemingen besteedt aandacht aan IFRS 9 in de andere informatie die samen met de jaarrekening is gepubliceerd. Evenmin wordt in de controleverklaring door de accountant melding gemaakt van IFRS 9.

\subsection{Best practices}

Een best practice is ons inziens Koninklijke Philips N.V. Deze onderneming beschrijft duidelijk per onderdeel van IFRS 9 de impact. Ondanks dat dit niet door middel van een tabel wordt gedaan, wordt duidelijk gemaakt dat de impact niet significant is voor IFRS 9 in zijn geheel. Per onderdeel van IFRS 9 wordt de impact kwantitatief inzichtelijk gemaakt, zowel voor de geconsolideerde jaarrekening als voor de enkelvoudige jaarrekening. Verder wordt aangegeven waardoor de impact wordt veroorzaakt bij het onderdeel Classificatie en waardering door aan te geven op welke wijze de verschillende soorten financiële instrumenten bij de overgang naar IFRS 9 worden geraakt. Bij het onderdeel Bijzondere waardevermindering wordt vermeld waarop het ECL-model betrekking heeft en voor welke financiële instrumenten de vereenvoudigde benadering wordt toegepast. Voor het onderdeel Hedge accounting wordt aangegeven dat de meeste hedges voldoen aan de vereisten van IFRS 9 en dat hedge accounting kan worden voortgezet, maar dat de interne hedgedocumentatie moet worden geactualiseerd evenals het beheersingssysteem. Ook wordt vermeld hoe wordt omgegaan met de cost of hedging voor forward-elementen van termijncontracten en voor de tijdswaarde bij opties.

De tekst over de transitietoelichting van Koninklijke Philips NV is opgenomen in Figuur 3.

\section{Empirische analyse IFRS 15}

\subsection{Impact bekend?}

Zoals uit tabel 9 blijkt, heeft 93\% van de onderzochte ondernemingen aangegeven dat de impact bekend is. 54\% van de ondernemingen waarvan de impact bekend is, heeft de impact ook gekwantificeerd. De ondernemingen waarbij de impact wel bekend is, maar die de impact niet gekwantificeerd hebben, hebben aangegeven dat IFRS 15 geen materiële impact heeft. Daardoor is de exacte impact minder relevant. Een deel van de ondernemingen die de impact gekwantificeerd heeft, heeft wel aangegeven 
Figuur 3. Best practice transitietoelichting IFRS 9: Koninklijke Philips NV, Annual report 2017, p. 119, 120

\author{
IFRS 9 Financial Instruments \\ IFRS 9 Financial Instruments brings together the classification and measurement, impairment and hedge accounting phases of the \\ IASB's project to replace IAS 39 Financial Instruments: Recognition and Measurement.
}

The new standard also introduces expanded disclosure requirements to IFRS 7 Financial Instruments: Disclosures and changes in presentation to IAS 1 Presentation of Financial Statements. These are expected to change the nature and extent of the Company's disclosures about its financial instruments particularly in the year of the adoption of the new standard.

The Company finalized the implementation of IFRS 9, except for the determination of the final IFRS 7 disclosures to be included in the Annual Report for 2018. These will be finalized in the coming year. The Company will adopt the new standard on the required effective date and will not restate comparative information. During 2017, Philips performed a detailed impact assessment of all three aspects of IFRS 9. Overall, the Company expects no significant impact on its statement of financial position and equity.

\title{
Classification and measurement
}

The Company noted no significant impact on its balance sheet or equity on applying the classification and measurement requirements of IFRS 9. The investments in equity shares are currently classified as available-for-sale financial assets with gains and losses recorded in other comprehensive income. Upon adopting IFRS 9, certain financial investments amounting to EUR 21 million (impact on Company financial statements is EUR 14 million) will change classification and measurement from Other comprehensive income to Fair value through profit or loss (FVPL). The related fair value gains of EUR 5 million (impact on Company financial statements is EUR 5 million) will be transferred from the available-for-sale financial assets reserve to Retained earnings on January 1, 2018.

The remaining available-for-sale equity investments amounting to EUR 396 million (impact on Company financial statements is EUR 130 million) will continue to be measured at fair value through Other comprehensive income as the Company has chosen the fair value through other comprehensive income (FVOCI) election for such investments. Accordingly, the new guidance will not affect the classification and measurement of these financial assets. However, gains or losses realized on the sale of financial assets at FVOCI will no longer be transferred to profit or loss on sale, but instead reclassified below the line from the FVOCI reserve to Retained earnings.

The debt investments of the Company amounting to EUR 29 million (impact on Company financial statements is nil) that are currently classified as available-for-sale will satisfy the conditions for classification as at FVOCI and hence there will be no change to the accounting for these assets.

The Company has debt investment amounting to EUR 0.6 million (impact on Company financial statements is nil) currently classified as held-to-maturity and measured at amortized cost which meets the conditions for classification at amortized cost under IFRS 9.

Loans as well as trade receivables are held to collect contractual cash flows and are expected to give rise to cash flows representing solely payments of principal and interest. The Company analyzed the contractual cash flow characteristics of those instruments and concluded that they meet the criteria for amortized cost measurement under IFRS 9. Therefore, reclassification for these instruments is not required except for receivables which are factored. The business model for such factored receivables amounting to EUR 48 million (impact on Company financial statements is nil) is hold to collect and sell and hence they will be booked at FVOCI.

There will be no impact on the Company's accounting for financial liabilities, as the new requirements only affect the accounting for financial liabilities that are designated at fair value through profit or loss, and the Company does not have any such liabilities. The derecognition rules have been transferred from IAS 39 Financial Instruments: Recognition and Measurement and have not been changed.

\section{Impairment}

The new impairment model requires the recognition of impairment provisions based on expected credit losses (ECL) rather than only incurred credit losses as is the case under IAS 39. The expected credit losses include forward-looking elements on all possible default events as well as historical loss data. It applies to financial assets classified at amortized cost, debt instruments measured at FVOCI, contract assets under IFRS 15 Revenue from Contracts with Customers, lease receivables, loan commitments and certain financial guarantee contracts. The Company will apply the simplified approach and record lifetime-expected losses on all trade receivables. Based on the assessments undertaken to date, the Company expects no material increase in the loss allowance for debt investments and financial assets held at amortized cost.

Additionally the Company also assessed the impact of the new impairment model on its intercompany financial assets (including receivables) recognized in the Company financial statements and concluded that there is no material increase in the loss allowance.

\section{Hedge accounting}

The Company has completed updates to its internal documentation and monitoring processes and concluded that all existing hedge relationships that are currently designated in effective hedging relationships will continue to qualify for hedge accounting under IFRS 9. Changes in the fair value of foreign exchange forward contracts attributable to forward points and in the time value of the option contracts will in future be deferred in costs of hedging reserve within equity. The deferred amounts will be recognized against the related hedged transaction when it occurs.

The Company has chosen not to retrospectively apply IFRS 9 on transition regarding the forward points of the forward contracts under IAS 39. As IFRS 9 does not change the general principles of how an entity accounts for effective hedges, applying the hedging requirements of IFRS 9 will not have a significant impact on Philips' financial statements.

\section{Transition}

IFRS 9 must be applied for financial years commencing on or after January 1, 2018 and it is fully endorsed by the EU. The Company will apply the new rules retrospectively from January 1,2018, with the practical expedients permitted under the standard. 
Tabel 9. Toelichting impact IFRS 15.

\begin{tabular}{|c|c|c|c|}
\hline & Aantal & $\%$ & $\%$ totaal \\
\hline \multicolumn{4}{|l|}{ Impact bekend } \\
\hline Impact gekwantificeerd zonder voorbehoud & 25 & $37 \%$ & $35 \%$ \\
\hline Impact gekwantificeerd met voorbehoud & 11 & $17 \%$ & $15 \%$ \\
\hline \multirow[t]{2}{*}{ Impact niet gekwantificeerd } & 31 & $46 \%$ & $43 \%$ \\
\hline & 67 & $100 \%$ & $93 \%$ \\
\hline \multicolumn{4}{|l|}{ Impact niet bekend } \\
\hline Impact materieel & 1 & $20 \%$ & $1 \%$ \\
\hline \multirow[t]{2}{*}{ Niet bekend of impact materieel is } & 4 & $80 \%$ & $6 \%$ \\
\hline & 5 & $100 \%$ & $7 \%$ \\
\hline Totaal & 72 & & $100 \%$ \\
\hline
\end{tabular}

dat de precieze impact nog kan wijzigen, bijvoorbeeld door veranderde interpretaties van IFRS 15.

Eén onderneming geeft aan dat de impact naar verwachting materieel zal zijn, maar dat de omvang van de impact nog niet bekend is. Bij vier ondernemingen is nog onduidelijk of er sprake zal zijn van een materiële impact.

\subsection{Significante impact?}

Van de onderzochte ondernemingen geeft 32\% aan dat de impact materieel is. Tabel 10 toont de verwachte impact per bedrijfstak. De bedrijfstakken die het meest geraakt worden door IFRS 15 zijn Telecommunications en Utilities. Bij Telecommunications gaat het vooral om de identificatie van prestatieverplichtingen (telefoon versus abonnement) en de verwerking van de kosten om contracten te verkrijgen. De verwerking van deze kosten is ook een belangrijk aandachtspunt bij Utilities, naast de vraag of gehandeld wordt als principaal of agent.

\subsection{Verwachte wijzigingen?}

Ook als de impact niet significant is, kunnen er wel wijzigingen optreden in de omzetverantwoording. 45 (63\%) van de onderzochte ondernemingen geeft aan welke wijzigingen er zullen optreden.

Tabel 11 geeft een overzicht van de wijzigingen. 21\% van de ondernemingen geeft aan dat er wijzigingen ontstaan door de nadere richtlijnen over het onderkennen van prestatieverplichtingen. Andere belangrijke wijzigingen zijn (a) het activeren van de kosten om een contract te verkrijgen, (b) betalingen aan klanten verantwoorden als vermindering van de omzet in plaats van als kosten, (c) de timing van omzetverantwoording en (d) licenties.

Tabel 10. Percentage ondernemingen dat materiële impact verwacht per bedrijfstak.

\begin{tabular}{|c|c|c|c|}
\hline \multirow[b]{2}{*}{ Bedrijfstak } & \multirow{2}{*}{$\begin{array}{c}\text { Bedrijfstak } \\
\text { Aantal }\end{array}$} & \multicolumn{2}{|c|}{ Materiële impact } \\
\hline & & Aantal & $\%$ \\
\hline Basic Materials & 8 & 2 & $25 \%$ \\
\hline Consumer Goods & 23 & 4 & $17 \%$ \\
\hline Consumer Services & 4 & 0 & $0 \%$ \\
\hline Health Care & 9 & 2 & $22 \%$ \\
\hline Industrials & 9 & 3 & $33 \%$ \\
\hline Oil \& Gas & 5 & 1 & $20 \%$ \\
\hline Technology & 3 & 1 & $33 \%$ \\
\hline Telecommunications & 6 & 6 & $100 \%$ \\
\hline Utilities & 5 & 4 & $80 \%$ \\
\hline Totaal & 72 & 23 & $32 \%$ \\
\hline
\end{tabular}

\subsection{Transitiemethode?}

Zoals eerder aangegeven zijn er twee methoden om de overgang naar IFRS 15 in de jaarrekening te verwerken, namelijk de volledig retrospectieve methode en de aangepaste retrospectieve methode.

$79 \%$ van de ondernemingen vermeldt welke methode gehanteerd zal worden. Van die ondernemingen gaat $37 \%$ de volledig retrospectieve methode hanteren en $63 \%$ de aangepaste retrospectieve methode. Zoals uit tabel 12 blijkt, varieert de methode per bedrijfstak. In de bedrijfstak Oil \& Gas is een duidelijke voorkeur voor de aangepaste retrospectieve methode, terwijl in de bedrijfstak Industrials een voorkeur voor de volledige retrospectieve methode bestaat.

Tabel 13 geeft de relatie aan tussen de toepassing van de transitiemethoden en het verwachte effect van IFRS 15. Van de ondernemingen die een materieel effect ver- 
Tabel 11. Verwachte wijzigingen in omzetverantwoording.

\begin{tabular}{lcc} 
& Aantal ondernemingen dat aanpassing genoemd heeft \\
Verwachte wijzigingen & Aantal & $\%$ \\
Prestatieverplichtingen & 15 & $21 \%$ \\
Kosten verkrijgen contract & 11 & $15 \%$ \\
Betalingen aan klanten & 10 & $14 \%$ \\
Timing omzetverantwoording & 8 & $11 \%$ \\
Licenties & 8 & $11 \%$ \\
Principaal-agent & 6 & $8 \%$ \\
Variabele vergoeding & 5 & $7 \%$ \\
Terugkoopverplichtingen & 4 & $6 \%$ \\
Retouren & 4 & $6 \%$ \\
Samenwerkingsverbanden & 3 & $4 \%$ \\
Opties voor klanten & 3 & $4 \%$ \\
Prijsconcessies & 2 & $3 \%$ \\
Significante financieringscomponent & 2 & $3 \%$ \\
Kosten voldoen contract & 2 & $3 \%$ \\
Allocatie transactieprijs & 1 & $1 \%$ \\
Garanties & 1 & $1 \%$ \\
Verlieslatende contracten & 1 & $1 \%$ \\
Bill-and-hold & 1 & $1 \%$ \\
Accijns & 1 & $1 \%$ \\
Totaal aantal ondernemingen & & 72 \\
\hline
\end{tabular}

Tabel 12. Transitiemethode per bedrijfstak.

\begin{tabular}{lccc} 
Bedrijfstak & $\begin{array}{c}\% \text { transitiemethode } \\
\text { vermeld }\end{array}$ & $\begin{array}{c}\text { Indien vermeld, \% } \\
\text { volledig retrospectief }\end{array}$ & $\begin{array}{c}\text { Indien vermeld, \% } \\
\text { aangepast retrospectief }\end{array}$ \\
Basic Materials & $63 \%$ & $40 \%$ & $60 \%$ \\
Consumer Goods & $61 \%$ & $50 \%$ & $50 \%$ \\
Consumer Services & $100 \%$ & $25 \%$ & $75 \%$ \\
Health Care & $100 \%$ & $22 \%$ & $78 \%$ \\
Industrials & $67 \%$ & $67 \%$ & $33 \%$ \\
Oil \& Gas & $100 \%$ & $0 \%$ & $100 \%$ \\
Technology & $100 \%$ & $33 \%$ & $67 \%$ \\
Telecommunications & $100 \%$ & $33 \%$ & $67 \%$ \\
Utilities & $100 \%$ & $40 \%$ & $60 \%$ \\
\hline
\end{tabular}

Tabel 13. Relatie tussen transitiemethode en verwachte impact.

\begin{tabular}{|c|c|c|c|}
\hline & $\begin{array}{c}\% \text { transitiemethode } \\
\text { vermeld }\end{array}$ & $\begin{array}{c}\text { Indien vermeld, \% } \\
\text { volledig retrospectief }\end{array}$ & $\begin{array}{c}\text { Indien vermeld, \% } \\
\text { aangepast retrospectief }\end{array}$ \\
\hline Wel impact & $100 \%$ & $43 \%$ & $57 \%$ \\
\hline Geen impact & $69 \%$ & $29 \%$ & $71 \%$ \\
\hline Impact nog niet bekend & $75 \%$ & $67 \%$ & $33 \%$ \\
\hline
\end{tabular}

wachten, geven alle ondernemingen aan welke methode gehanteerd zal worden. $43 \%$ kiest hiervan voor de volledig retrospectieve methode. Als er geen significante impact verwacht wordt, geeft $69 \%$ van de ondernemingen aan welke methode gehanteerd zal worden. Van de ondernemingen die een methode noemen terwijl de verwachte impact niet significant is, kiest $29 \%$ voor de volledig retrospectieve methode.

Bij de overgang naar IFRS 15 zijn verschillende vereenvoudigingen mogelijk. Slechts een deel van de on- dernemingen geeft aan van welke vereenvoudigingen er gebruik gemaakt zal worden. Bij de volledig retrospectieve methode geeft $33 \%$ van de ondernemingen aan welke vereenvoudigingen er gebruikt zullen worden en bij de aangepaste retrospectieve methode $28 \%$.

\subsection{Aandacht in bestuursverslag en controleverklaring?}

$22 \%$ van de ondernemingen besteedt ook aandacht aan IFRS 15 in de andere informatie die samen met de jaar- 
rekening gepubliceerd wordt. $\mathrm{Bij} 10 \%$ van de ondernemingen makt de accountant melding van IFRS 15 in de controleverklaring.

\subsection{Best practices}

Een best practice is Volvo Group. Deze onderneming beschrijft duidelijk wat de impact van IFRS 15 zal zijn door aan te geven hoe de 2017-cijfers beïnvloed worden door de nieuwe standaard. Daarbij worden de volgende overzichten getoond:

- Impact op de omzet per segment per kwartaal;

- Impact op operating income per segment per kwartaal;

- Impact op de operating margin per segment per kwartaal;

- Impact op de volledige winst-en-verliesrekening per kwartaal;

- Impact op de balans per 1 januari, 31 maart, 30 juni, 31 oktober en 31 december 2017.

De tekst en verschillende van deze overzichten zijn opgenomen als Figuur 4.

\section{Conclusies}

IAS 8 verplicht ondernemingen om, indien mogelijk, de verwachte impact van een nieuwe standaard te kwantificeren. Onze analyse van deze toelichtingen geeft een beeld van het verwachte effect van IFRS 9 en IFRS 15.

Minimaal $84 \%$ van de onderzochte ondernemingen geeft aan dat de impact voor de verschillende onderdelen van IFRS 9 bekend is. Bij $9 \%$ van de onderzochte ondernemingen lichten de ondernemingen toe dat sprake is van een materiële impact. De bedrijfstakken Oil \& Gas, Utilities en Consumer Goods hebben relatief de meeste ondernemingen met een materiële impact. Deze materiële impact komt uit de onderdelen Classificatie en waardering en Bijzondere waardevermindering. Bij het onderdeel Classificatie en waardering komen de meeste soorten wijzigingen naar voren, terwijl bij het onderdeel Bijzondere waardevermindering het alleen gaat om een hogere of lagere bijzondere waardevermindering. Van de transitiebepalingen wordt in $47 \%$ van de gevallen aangegeven dat geen vergelijkende cijfers hoeven te worden vermeld. Van de andere transitiebepalingen wordt de keuze voor de simplified approach bij ECL's toegelicht in iets meer dan een kwart van de onderzochte ondernemingen.

93\% van de ondernemingen geeft aan dat de impact van IFRS 15 bekend is. Bij 32\% van de onderzochte ondernemingen is de impact naar verwachting materieel. De bedrijfstakken die het meest geraakt worden zijn Telecommunications en Utilities. IFRS 15 heeft vooral impact vanwege (a) de nadere richtlijnen over het onderkennen van prestatieverplichtingen, (b) het activeren van de kosten om een contract te verkrijgen en (c) het verantwoorden van betalingen aan klanten als vermindering van de omzet. De meerderheid geeft aan de aangepaste retrospectieve methode te zullen hanteren.

Figuur 4. Best practice impact van IFRS 15: Volvo Group Annual and Sustainability Report 2017, pp. 167-173

Implementation of new accounting standards

As from January 1, 2018 Volvo Group applies IFRS 9 Financial instruments and IFRS 15 Revenue from Contracts with Customers. These standards are applied retrospectively but with the difference in relation to presenting comparative financial information for 2017.

Opening balance 2017

For IFRS 15, the opening balance for 2017 is adjusted in accordance with the new standard and the transition effect is recognized as a decrease in equity with SEK $712 \mathrm{M}$. The reported financial information for 2017 is restated accordingly for comparison purposes. For IFRS 9, the opening balance for 2017 has not been affected.

IFRS 15 Revenue from Contracts with Customers

IFRS 15 replaces IAS 11 Construction contracts, IAS 18 Revenue and the related interpretations IFRIC 13, 15,18 and SIC-31. IFRS 15 represents a new framework for recognizing revenue from contracts with customers and with additional disclosure requirements.

The major impact of implementation of IFRS 15 is related to sales transactions of vehicles with various residual value commitments, e.g. buybacks and tradebacks, and the assessment if control has been transferred from Volvo Group to the customer.

The criterion of transferring control is based on if the customer has a significant economic incentive to exercise the residual value commitment or not. If the customer is considered to have a significant economic incentive to exercise the residual value commitment to return the vehicle, revenue is recognized over the residual value commitment period as an operating lease transaction in accordance with IAS 17.

Various factors are assessed when considering if significant economic incentives exist, such as repurchase price in relation to the expected market value at the date of the repurchase and historical return rates. These are new criteria compared with the former revenue recognition model, where the residual value was compared with the sales price. The accounting model has not change, however the criteria for when to apply the model are different. 
If the customer is not considered to have a significant economic incentive to exercise the residual value commitment to return the vehicle, the revenue is recognized in accordance with the right of return model. Hence, a major portion of revenue and margin is recognized at inception of the contract. A refund liability and an asset related to the right to recover the vehicle from the customer on settling the refund liability are recognized in the balance sheet. If the vehicle is not returned the refund liability is recognized as revenue and the asset is expensed. This is a change compared to the former model, where full revenue is recognized at the inception of the contract with a contingent liability.

The effect of the two new models is a later recognition of revenue with an increase of assets with SEK 6,516 M mainly related to assets under operating lease and right of return assets and an increase of liabilities with SEK 7,725 M mainly related to deferred leasing income and residual value liabilities as of December 31,2017. The corresponding effect is a net decrease in equity with SEK 1,209 M (net of tax) consisting of opening balance effect of SEK $712 \mathrm{M}$ and a decrease of Income for the period for 2017 with SEK 497 M, whereof SEK 650 M affecting Operating income for 2017.

The effect from the transition to IFRS 15 is presented on page 168-176 with restatements on net sales, operating income and operating margin divided by segment and quarter. Further is a presentation of income statement per quarter and full year for 2017, the opening balance sheet for 2017 and balance sheet per quarter and year to date.

\begin{tabular}{|c|c|c|c|}
\hline \multirow{2}{*}{$\begin{array}{l}\text { Net sales } \\
\text { SEKM }\end{array}$} & \multicolumn{3}{|c|}{ First quarter } \\
\hline & $\begin{array}{l}\text { Previously } \\
\text { reported } 2017\end{array}$ & $\begin{array}{r}\text { Restatement } \\
\text { IFRS } 15\end{array}$ & $\begin{array}{r}\text { After } \\
\text { restatement }\end{array}$ \\
\hline Trucks & 49,467 & -366 & 49,101 \\
\hline Construction Equipment & 16,163 & -61 & 16,101 \\
\hline Buses & 5,548 & -7 & 5,540 \\
\hline Volvo Penta & 2,701 & - & 2,701 \\
\hline Group Functions \& Other incl. eliminations & 773 & - & 773 \\
\hline Industrial Operations & 74,652 & -435 & 74,217 \\
\hline Financial Services & 2,892 & - & 2,892 \\
\hline Eliminations & -179 & - & -179 \\
\hline Volvo Group & 77,365 & -435 & 76,930 \\
\hline \multirow[t]{2}{*}{ Operating income } & \multicolumn{3}{|c|}{ First quarter } \\
\hline & $\begin{array}{l}\text { Previously } \\
\text { reported } 2017\end{array}$ & $\begin{array}{c}\text { Restatement } \\
\text { IFRS } 15\end{array}$ & $\begin{array}{r}\text { After } \\
\text { restatement }\end{array}$ \\
\hline Trucks & 4,910 & -182 & 4,728 \\
\hline Construction Equipment & 1,617 & -2 & 1,615 \\
\hline Buses & 101 & -11 & 90 \\
\hline Volvo Penta & 419 & - & 419 \\
\hline Group Functions \& Other incl. eliminations & -549 & - & -549 \\
\hline Industrial Operations & 6,499 & -195 & 6,304 \\
\hline Financial Services & 531 & - & 531 \\
\hline Volvo Group & 7,029 & -195 & 6,834 \\
\hline
\end{tabular}

\section{CONSOLIDATED INCOME STATEMENT}

\begin{tabular}{|c|c|c|c|}
\hline \multirow[b]{2}{*}{ SEKM } & \multicolumn{3}{|c|}{ First quarter } \\
\hline & $\begin{array}{l}\text { Previously } \\
\text { reported } 2017\end{array}$ & $\begin{array}{l}\text { Restatement } \\
\text { IFRS } 15\end{array}$ & $\begin{array}{r}\text { After } \\
\text { restatement }\end{array}$ \\
\hline Net sales & 77,365 & -435 & 76,930 \\
\hline Cost of sales & $-57,835$ & 239 & $-57,596$ \\
\hline Gross income & 19,530 & -195 & 19,335 \\
\hline Research and development expenses & $-3,994$ & - & $-3,994$ \\
\hline Selling expenses & $-6,942$ & - & $-6,942$ \\
\hline Administrative expenses & $-1,286$ & - & $-1,286$ \\
\hline Other operating income and expenses & -616 & - & -616 \\
\hline $\begin{array}{l}\text { Income/loss from investments in Joint Ventures } \\
\text { and associated companies }\end{array}$ & 340 & - & 340 \\
\hline Income from other investments & -2 & - & -2 \\
\hline Operating income & 7,029 & -195 & 6,834 \\
\hline Interest income and similar credits & 50 & - & 50 \\
\hline Interest expenses and similar charges & -463 & - & -463 \\
\hline Other financial income and expenses & -177 & - & -177 \\
\hline Income after financial items & 6,440 & -195 & 6,245 \\
\hline Income taxes & $-1,624$ & 45 & $-1,579$ \\
\hline Income for the period & 4,816 & -150 & 4,666 \\
\hline \multicolumn{4}{|l|}{ *Attributable to: } \\
\hline Equity holders of the parent company & 4,730 & -150 & 4,580 \\
\hline \multirow[t]{2}{*}{ Minority interests } & 85 & - & 85 \\
\hline & 4,816 & -150 & 4,666 \\
\hline Basic earnings per share, SEK & 2.33 & -0.08 & 2.25 \\
\hline Diluted earnings per share, SEK & 2.33 & -0.08 & 2.25 \\
\hline
\end{tabular}




\begin{tabular}{|c|c|c|c|c|c|}
\hline \multicolumn{6}{|l|}{ CONSOLIDATED BALANCE SHEET } \\
\hline \multirow[b]{2}{*}{ SEKM } & \multicolumn{3}{|c|}{ Volvo Group } & \multicolumn{2}{|c|}{ Volvo Group } \\
\hline & $\begin{array}{r}\text { Previously reported } \\
\text { Dec 31,2017 }\end{array}$ & $\begin{array}{l}\text { Restatement } \\
\text { IFRS } 15\end{array}$ & $\begin{array}{c}\text { After IFRS } 15 \\
\text { restatement } \\
\text { Dec } 31,2017\end{array}$ & $\begin{array}{l}\text { Restatement } \\
\text { IFRS } 9\end{array}$ & $\begin{array}{r}\text { After } \\
\text { restatement } \\
\text { Jan 1, 2018 }\end{array}$ \\
\hline \multicolumn{6}{|l|}{ Assets } \\
\hline \multicolumn{6}{|l|}{ Non-current assets } \\
\hline Intangible assets & 35,893 & - & 35,893 & - & 35,893 \\
\hline \multicolumn{6}{|l|}{ Tangible assets } \\
\hline Property, plant and equipment & 53,348 & - & 53,348 & - & 53,348 \\
\hline Assets under operating leases & 37,166 & 4,424 & 41,590 & -77 & 41,513 \\
\hline \multicolumn{6}{|l|}{ Financial assets } \\
\hline Investments in Joint Ventures and associated companies & 10,525 & - & 10,525 & - & 10,525 \\
\hline Other shares and participations & 699 & - & 699 & - & 699 \\
\hline Non-current customer-financing receivables & 57,173 & - & 57,173 & -254 & 56,919 \\
\hline Prepaid pensions & 252 & - & 252 & - & 252 \\
\hline Non-current interest-bearing receivables & 2,335 & - & 2,335 & - & 2,335 \\
\hline Other non-current receivables & 4,281 & 3,813 & 8,094 & - & 8,094 \\
\hline Deferred tax assets & 11,782 & 111 & 11,893 & 129 & 12,022 \\
\hline Total non-current assets & 213,455 & 8,348 & 221,803 & -202 & 221,601 \\
\hline \multicolumn{6}{|l|}{ Current assets } \\
\hline Inventories & 52,701 & - & 52,701 & - & 52,701 \\
\hline \multicolumn{6}{|l|}{ Current receivables } \\
\hline Customer-financing receivables & 52,205 & - & 52,205 & -142 & 52,062 \\
\hline Tax assets & 1,567 & - & 1,567 & - & 1,567 \\
\hline Interest-bearing receivables & 1,166 & - & 1,166 & - & 1,166 \\
\hline Internal funding & - & - & - & - & - \\
\hline Accounts receivable & 40,774 & $-2,585$ & 38,189 & -26 & 38,163 \\
\hline Other receivables & 14,305 & 753 & 15,058 & - & 15,058 \\
\hline Non interest-bearing assets held for sale & 51 & - & 51 & - & 51 \\
\hline Interest-bearing assets held for sale & - & - & - & - & - \\
\hline Marketable securities & 178 & - & 178 & - & 178 \\
\hline Cash and cash equivalents & 36,092 & - & 36,092 & - & 36,092 \\
\hline Total current assets & 199,039 & $-1,832$ & 197,207 & -169 & 197,038 \\
\hline Total assets & 412,494 & 6,516 & 419,010 & -371 & 418,639 \\
\hline \multicolumn{6}{|l|}{ Equity and liabilities } \\
\hline $\begin{array}{l}\text { Equity attributable to the equity holders of the parent com- } \\
\text { pany }\end{array}$ & 107,069 & $-1,209$ & 105,861 & -371 & 105,490 \\
\hline Minority interests & 1,941 & - & 1,941 & - & 1,941 \\
\hline Total equity & 109,011 & $-1,209$ & 107,802 & -371 & 107,431 \\
\hline \multicolumn{6}{|l|}{ Non-current provisions } \\
\hline Provisions for post-employment benefits & 14,476 & - & 14,476 & - & 14,476 \\
\hline Provisions for deferred taxes & 5,353 & -237 & 5,116 & - & 5,116 \\
\hline Other provisions & 9,318 & -835 & 8,484 & - & 8,484 \\
\hline \multicolumn{6}{|l|}{ Non-current liabilities } \\
\hline Bond loans & 48,962 & - & 48,962 & - & 48,962 \\
\hline Other loans & 24,942 & - & 24,942 & - & 24,942 \\
\hline Internal funding & - & - & - & - & - \\
\hline Other liabilities & 22,309 & 6,421 & 28,730 & - & 28,730 \\
\hline Current provisions & 10,806 & -391 & 10,416 & - & 10,416 \\
\hline \multicolumn{6}{|l|}{ Current liabilities } \\
\hline Loans & 53,771 & - & 53,771 & - & 53,771 \\
\hline Internal funding & - & - & - & - & - \\
\hline Non interest-bearing liabilities held for sale & 0 & - & - & - & 0 \\
\hline Interest-bearing liabilities held for sale & - & - & - & - & - \\
\hline Trade payables & 65,346 & - & 65,346 & - & 65,346 \\
\hline Tax liabilities & 1,699 & - & 1,699 & - & 1,699 \\
\hline Other liabilities & 46,501 & 2,766 & 49,267 & - & 49,267 \\
\hline Total equity and liabilities & 412,494 & 6,516 & 419,010 & -371 & 418,639 \\
\hline
\end{tabular}

Drs. C.M. (Kees) Roozen RA is werkzaam als director bij de afdeling Department of Professional Practice van KPMG Accountants NV.

- Prof. dr Maarten Pronk is hoogleraar aan de Erasmus Universiteit Rotterdam en associate partner bij de afdeling Professional Practice van EY.

\section{Dankwoord}

De auteurs hebben deze bijdrage geschreven op persoonlijke titel. Zij bedanken Elisa van Bruggen, Jan Chan en Ilse Langelaan hartelijk voor hun waardevolle bijdrage aan het empirische onderzoek. Tevens danken zij Erik Hoogcarspel en Dick Korf voor hun commentaar bij een eerdere versie van dit artikel. 


\section{Noten}

1. De definitieve IFRS 9 roept echter wel de vraag op of deze standaard minder complex is dan IAS 39.

2. De kritiek op IAS 39 is in dit verband dat de bijzondere waardeverminderingen voor kredietverliezen too little en too late werden gevormd en daarmee onvoldoende buffers en om die reden een procyclische werking hebben.

3. Naast deze doelen had de IASB op basis van de Norwalk Agreement uit 2002 ook het doel om de verschillen tussen US GAAP en IFRS te verkleinen. Dit doel is echter niet behaald. Zie daartoe ook de Project Summary van de IASB over IFRS 9 Financial instruments, July 2014.

4. Volledigheidshalve merken we op dat financiële verplichtingen die onderdeel uitmaken van een handelsportefeuille tegen FVTPL worden gewaardeerd..

5. Daarnaast is het op grond van IFRS 9.4.2.2 mogelijk om deze financiële verplichtingen tegen FVTPL te waarderen als een groep van financiële verplichtingen of financiële activa op reële waarde worden beheerd en hun performance wordt geëvalueerd op een reële waardebasis.

6. Stage 3 ECLs komen in grote lijnen overeen met de incurred credit losses uit IAS 39 met dat verschil dat onder het ECL-model ook rekening wordt gehouden met toekomstige inschattingen van kredietverliezen. 'In grote lijnen', omdat onder het incurred credit loss-model van IAS 39 ook al rekening wordt gehouden met te verwachten kredietverliezen (het verschil tussen de boekwaarde en de recoverable amount). Er is nog wel een verschil tussen de best estimate-benadering van IAS 39 en de probability weighted-benadering van IFRS 9.

7. Onder Cost of hedging wordt verstaan de tijdswaarde van (gekochte) opties, het forward-element van termijncontracten en de vreemdevalutabasis-spreads van cross currency swaps. Onder de cost of hedging-benadering worden deze kosten in het eigen vermogen opgenomen en bij een transactie-gerelateerde afgedekte positie als kosten van de transactie begrepen, terwijl deze bij een tijdsperiode gerelateerde afgedekte positie worden geamortiseerd over de looptijd van de afgedekte positie. Onder IFRS 9 moet de tijdswaarde van (gekochte) opties worden verwerkt op basis van de cost of hedging-benadering, terwijl deze verwerkingswijze optioneel is voor forward-elementen van termijncontracten en voor vreemdevalutabasis-spreads van cross currency swaps.

8. Het onderzoek 'Results on the fact-finding exercise on disclosure of the impact of the new accounting standards in the 2016 annual and 2017 interim IFRS financial statements' van ESMA, 27 oktober 2017 (ESMA 2017a, ESMA32-63-364) focust niet alleen op financiële instellingen; ook zijn niet-financiële instellingen onderzocht in de bouw, telecom en software industrie (IFRS 9) en in de utiliteitsbouw en industriële ondernemingen (IFRS 15).

9. Ook op 3 april 2018 heeft ESMA een rapport gepubliceerd over de 'Enforcement and Regulatory Activiteits of Accounting Enforcers in 2017 (ESMA 2018, ESMA 32-63-424), waarin zij benadrukt dat één van de gezamenlijke Europese enforcement-prioriteiten ligt op het gebied van de toelichtingen over de nieuwe standaarden, IFRS 9 en IFRS 15 voor de IFRS 2017-jaarrekeningen.

10. FTSE Russel per 15 mei 2018. Met dank aan Frances Brett van FTSE Russell.

11. Zie ESMA rapport van 3 april 2018 (ESMA 2018, ESMA 32-63-424), pagina 17.

12. Zie KPMG-publicatie van juni 2018, een onderzoek naar de transitietoelichtingen bij 55 beursgenoteerde ondernemingen in Nederland, waarbij zowel naar de details van de toelichting, de verwachte impact en de transitiebenadering is gekeken. Daarin staat dat $91 \%$ van de onderzochte 55 ondernemingen heeft aangegeven dat de impact niet materieel is.

13. Dit effect hebben we zelf berekend. In een aantal gevallen is alleen het netto-effect gegeven en is het belastingeffect niet afzonderlijk vermeld. In dat geval is het effect voor belasting berekend met behulp van de effectieve belastingvoet.

\section{Literatuur}

European Securities and Markets Authority (ESMA) (2016a) Public statement: Issues for consideration in implementing IFRS 15 : Contracts with Customers. ESMA/2016/1148. https://www.esma. europa.eu/document/public-statement-issues-consideration-in-implementing-ifrs- 15

- European Securities and Markets Authority (ESMA) (2016b) Public statement: Issues for consideration in implementing IFRS 9: Financial Instruments. ESMA/2016/1563. https://www.esma.europa.eu/ document/issues-consideration-in-implementing-ifrs-9-financial-instruments

- European Securities and Markets Authority (ESMA) (2017a) Summary of results of the fact-finding exercise on IFRS 9 and IFRS 15. ESMA32-63-364. https://www.esma.europa.eu/document/summary-results-fact-finding-exercise-ifrs-9-and-ifrs-15

- European Securities and Markets Authority (ESMA) (2017b) Public Statement: European common enforcement priorities for 2017 IFRS financial statements. ESMA32-63-340. https://www.esma.europa. eu/document/public-statement-european-common-enforcement-priorities-2017-ifrs-financial-statements

- European Securities and Markets Authority (ESMA) (2018) Report: Enforcement and Regulatory Activities of Accounting Enforcers in 2017. ESMA32-63-424. https://www.esma.europa.eu/document/enforcement-and-regulatory-activities-accounting-enforcers-in-2017

- IFRS Interpretations Committee (2017) IFRIC Update mei 2017, IFRS 9 Financial Instruments - financial assets eligible for the election to present changes in fair value in OCI. London, IASB. https:// www.ifrs.org/-/media/feature/news/updates/ifrs-ic/2017/ifric-update-may-2017.pdf

- IFRS Interpretations Committee (2017) IFRIC Update september 2017, IFRS 9 Financial Instruments - financial assets eligible for the election to present changes in fair value in OCI. London, IASB. https:// www.ifrs.org/news-and-events/updates/ifric-updates/september-2017/

- International Accounting Standards Board (IASB) (2014) Project summary IFRS 9 Financial Instruments. London, IASB. http:// 
archive.ifrs.org/Current-Projects/IASB-Projects/Financial-Instruments-A-Replacement-of-IAS-39-Financial-Instruments-Recognitio/Documents/IFRS-9-Project-Summary-July-2014.pdf

- International Accounting Standards Board (IASB) (2018) IAS 8: Accounting Policies, Changes in Accounting Estimates and Errors. https://www.ifrs.org/issued-standards/list-of-standards/ias-8-accounting-policies-changes-in-accounting-estimates-and-errors/

- International Accounting Standards Board (IASB) (2018) IFRS 9: Financial Instruments. https:/www.ifrs.org/issued-standards/list-ofstandards/ifrs-9-financial-instruments/

- International Accounting Standards Board (IASB) (2018) IFRS 15: Revenue from Contracts with Customers. https://www.ifrs. org/issued-standards/list-of-standards/ifrs-15-revenue-from-contracts-with-customers/

- KPMG (2017) Application guidance IFRS 9 for corporates - Are you good to go? London: ISG, KPMG. https:/home.kpmg.com/xx/ en/home/insights/2017/09/financial-instruments-corporates-implementation-guidance-ifrs9-ias39-ifrs7-280917.html

- KPMG (2017) Insights to IFRS 2017/2018, 14th edition. KPMG's practical guide to IFRS. London: ISG, KPMG. https://home.kpmg. $\mathrm{com} / \mathrm{xx} / \mathrm{en} / \mathrm{home} / \mathrm{services/audit/international-financial-report-}$ ing-standards/ifrs-toolkit/ifrs-insights-practical-application-guide. html

- KPMG (2018) IFRS 9, 15 and 16 - a leap forward, KPMG's 2017 Annual report market watch, Amstelveen, KPMG. https://assets. $\mathrm{kpmg}$.com/content/dam/kpmg/nl/pdf/2018/sector/financiele-dienstverlening/ifrs-9-15-16-a-leap-forward.pdf

- PwC (2017) Manual of Accounting - IFRS 2018, supplement 2018, global edition, December 2017, London, PwC. https://www.pwc. com/gx/en/services/audit-assurance/ifrs-reporting/manual-of-accounting.html

\section{Bijlage}

Overzicht onderzochte jaarrekeningen.

\begin{tabular}{|c|c|c|c|}
\hline $\begin{array}{l}\text { quide SA } \\
\text { SE } \\
\text { American PLC } \\
\text { ser-Busch InBev NV } \\
\text { r Mittal SA } \\
\text { Holding N.V. } \\
\text { Zeneca plc } \\
\text { Copco AB } \\
\text { SE } \\
\text { AG } \\
\text { AG } \\
\text { American Tobacco plc } \\
\text { oup plc }\end{array}$ & rrijk & $\begin{array}{l}\text { into Group } \\
\text { e Group } \\
\text { I Dutch Shell plc } \\
\text { n SA } \\
\text { i SA } \\
\text { SE } \\
\text { eider Electric SE* } \\
\text { ens AG } \\
\text { il ASA } \\
\text { onica SA } \\
\text { or ASA } \\
\text { SA } \\
\text { ver NV } \\
\text { SA } \\
\text { fone Group plc } \\
\text { wagen AG } \\
\text { Group }\end{array}$ & $\begin{array}{l}\text { rijk } \\
\text { e } \\
\text { igd Koninkrijk } \\
\text { e } \\
\text { rijk } \\
\text { rland } \\
\text { erland } \\
\text { land } \\
\text { rijk } \\
\text { rijk } \\
\text { iigd Koninkrijk } \\
\text { erland } \\
\text { hd } \\
\text { erland } \\
\text { marken } \\
\text { rijk } \\
\text { rijk } \\
\text { land }\end{array}$ \\
\hline
\end{tabular}

* Alleen opgenomen in de onderzoekspopulatie voor IFRS 15, omdat IFRS 9 vervroegd toegepast is in de 2017 jaarrekening. 